\title{
Fish as a source of (micro)nutrients to combat hidden hunger in Zambia
}

\author{
Nils Nölle ${ }^{1} \cdot$ Sven Genschick ${ }^{2,3} \cdot$ Klaus Schwadorf $^{4} \cdot$ Holger Hrenn $^{4} \cdot$ Sonja Brandner ${ }^{4} \cdot$ Hans Konrad Biesalski $^{1}$
}

Received: 28 May 2019 / Accepted: 30 June 2020 / Published online: 7 July 2020

(C) The Author(s) 2020, corrected publication 2021

\begin{abstract}
Fish is an excellent source of protein, but can also be a good source of micronutrients. In Zambia fish is the main animal food source for poor women and children, two groups which are likely to suffer from inadequate micronutrient supply (hidden hunger). Although the potential of fish to combat hidden hunger is increasingly recognized and fisheries and aquaculture have been identified as key resources in addressing food and nutrition security issues in Zambia, only limited information on the nutrient composition of consumed fish species and products is available. Thus the objectives of this paper are to give a quantitative description of the nutritional composition of fish and fish products consumed in Zambia, and to estimate their potential to the Recommended Daily Intakes (RDIs) of micronutrients. Therefore approximately forty fish species in various kinds of processing were collected and prepared following local customs. Samples were analysed for macronutrients such as protein and fat. Contents of B-vitamins and minerals were also analysed. Protein content was overall similar, while fat content and fatty acid composition varied considerably. Most fish contained high amounts of niacin and cobalamin, but small fish usually contained the most cobalamin. Small fish contained up to 32 times the amount of calcium than other fish and often contained more iron and zinc, too. Overall small fish species, which are commonly consumed by poor women and children, can be used to combat hidden hunger in Zambia, due to high levels of cobalamin, calcium, iron and zinc.
\end{abstract}

Keywords Hidden hunger $\cdot$ Malnutrition $\cdot$ Micronutrients $\cdot$ Zambia $\cdot$ Fish $\cdot$ Fish products

\section{Introduction}

Hidden hunger describes the phenomenon where a person is deficient in vitamins, minerals, and in some cases essential amino or fatty acids. The condition is called hidden because many micronutrient deficiencies remain hidden until clinical

Electronic supplementary material The online version of this article (https://doi.org/10.1007/s12571-020-01060-9 ) contains supplementary material, which is available to authorized users.

Nils Nölle

noelle@uni-hohenheim.de

Sven Genschick

sven.genschick@giz.de

Klaus Schwadorf

klaus.schwadorf@uni-hohenheim.de

Holger Hrenn

holger.hrenn@uni-hohenheim.de

Sonja Brandner

buecherbabette@gmx.de symptoms of the deficiency are detected. These subclinical deficiencies can lead to impaired health in affected people and hamper proper growth and neurological development in the case of children. Women and children usually suffer the highest risk of hidden hunger (Biesalski 2013). As in many other developing countries, food and nutrition insecurity are widespread
Hans Konrad Biesalski

biesal@uni-hohenheim.de

1 University of Hohenheim, Institute of Nutritional Science, Stuttgart, Germany

2 WorldFish Zambia Office, Plot 18944 Lunbansenshi Close, OlympiaOff Katima Mulilo Road, Lusaka, Zambia

3 Present address: German Corporation for International Cooperation GmbH (GIZ), Eschborn, Germany

4 Core Facility Hohenheim,Analytical Chemistry Unit, University of Hohenheim, Stuttgart, Germany 
in Zambia, and therefore hidden hunger is a significant public health concern. Acute and chronic micronutrient deficiencies, for instance of calcium, iron, folate and vitamin B12, are commonly found across rural and urban population groups (National Food and Nutrition Commission of Zambia [NFNC] 2011; Halimatou et al. 2014; Central Statistics Office [CSO] 2016). Approximately 50\% of the population (7.4 million people) in Zambia are malnourished. The prevalence of the stunting of children under five years old (40\%), being underweight (15\%), and wasting (5\%) is high (FAO 2017; Central Statistics Office [CSO] 2014). Inadequate food and nutrient intake is associated with diets of low diversity, especially among the poor. Over $50 \%$ of the population can only afford 1-2 meals per day, commonly dominated by staples such as maize, cassava or other starchy roots served with dark green leafy vegetables (Nyirenda et al. 2007; Central Statistics Office [CSO] 2016). Additionally, the consumption of animal-source foods, such as meat, eggs and dairy is low (Longley et al. 2014), with fish being the most frequently consumed animal-source food (Hichaambwa 2012).

Inland fisheries are the most important source of fish and the main source of fish for poor households in Zambia (Genschick et al. 2018). As proper cold chains are often absent, fish from inland fisheries are often processed regardless of size. The most common processing techniques are sundrying or smoking. The smoking process commonly practiced in Zambia takes several hours and dries the fish almost completely. Processing reduces post-harvest losses and increases options for storage, transport and retailing of fish, a highly perishable food commodity (Béné \& Heck 2005; Genschick et al. 2017). Despite the wide variety of fish species, Genschick et al. (2018) showed that poor consumers in urban Lusaka mostly focus on small fish species for consumption such as Kapenta, Mintesa or Chisense (scientific names in Tables 1 and 2) as they are usually cheaper. In other regions of Zambia, other small fish species, members of the Barbus (Tables 1 and 2) family for example, complement and/or replace these species, although overall scientific data on consumption in other regions is often lacking. Also widely available to consumers is a mix of different fish species commonly sold as Kasepa, which consists of a wide variety of small fish species, but can also include juvenile specimen of otherwise larger fish species (Carl Huchzermeyer, personal communication). These small fish are usually consumed whole, including bones, head and innards (Mintesa is an exception to this rule, as it is usually gutted) and are often sourced in their dried form (Longley et al. 2014; Genschick et al. 2018). If poor consumers can afford to eat larger fish, they usually belong to a richer socio-economic group amongst the poor (Marinda et al. 2018). In most cases, only the flesh of large fish is eaten, while the rest is usually discarded (Longley et al. 2014). Despite being the most consumed animal-source food, a study in urban Lusaka showed that mean daily intakes of fish are actually low, regardless of species. Men and women were found to consume $110.3 \mathrm{~g}$ and $91.4 \mathrm{~g}$ of fish per day, respectively. Children were found to consume $36.9 \mathrm{~g}$ to $49.0 \mathrm{~g}$ of fish per day, depending on their age (Marinda et al. 2018).

Fish supply from inland fisheries is stagnating due to diminishing fish populations, often because of unsustainable fishing practices (Tweddle et al. 2015). Yet, Zambia has successfully managed to increase its fish production in the last decade in order to meet the growing demand. For 2014, the yearly fish supply per capita rate in Zambia was estimated at $11 \mathrm{~kg}$ per capita, i.e. an increase of $62 \%$ compared to $6.8 \mathrm{~kg}$ per capita in 2004 (Kaminski et al. 2018). This increase was triggered by a recent growth in commercial aquaculture and a steady increase in fish imports (Kaminski et al. 2018; Genschick et al. 2017). Most of the domestic production consists of large tilapia (around 99\% of total production volume) and is mostly targeted to an urban, middle to higher-income, consumer base. Although this fish is colloquially called tilapia the actual species is usually always Oreochromis niloticus, while the species Tilapia sparrmanii, is known under the local name Matuku.

Imported fish is more accessible for lower income groups, but remains cost prohibitive for large parts of poor households (Genschick et al. 2018; Kaminski et al. 2018). Therefore the yearly fish supply per capita rate might be much lower for this group than estimated.

The importance of fish for food and nutrition security is increasingly recognized, as is its potential in addressing hidden hunger (Horton et al. 2008; Thilsted et al. 2016). Fisheries and aquaculture have been also identified as a key resource in addressing food and nutrition security issues in Zambia, featuring prominently in the national development agenda (National Food and Nutrition Commission of Zambia [NFNC] 2011). Yet, only very limited information on the nutrient composition of consumed fish species and products is available (Steiner-Asiedu et al. 1993; Nyirenda 2009; Haug et al. 2010). This is in stark contrast with Asian countries such as Bangladesh, where several studies have generated detailed nutrient composition profiles for many of the locally consumed fish species (Larsen et al. 2000; Roos et al. 2002, 2007; Bogard et al. 2015).

The objectives of this paper are therefore to first give a quantitative description of the nutritional composition of fish species consumed in Zambia, including processed fish, fish from aquaculture and imported fish. From this, nutrient composition profiles similar to those in Bangladesh can be derived. The second objective is to estimate the potential contribution of fresh and processed fish to the Recommended Daily Intakes (RDIs) of micronutrients, with a special focus on women and children (Bogard et al. 2015). Specific nutrients considered in this study are for example folate, vitamin B12, calcium, iron and zinc, because deficiencies in these nutrients have been found to be widespread in Zambia (Halimatou et al. 


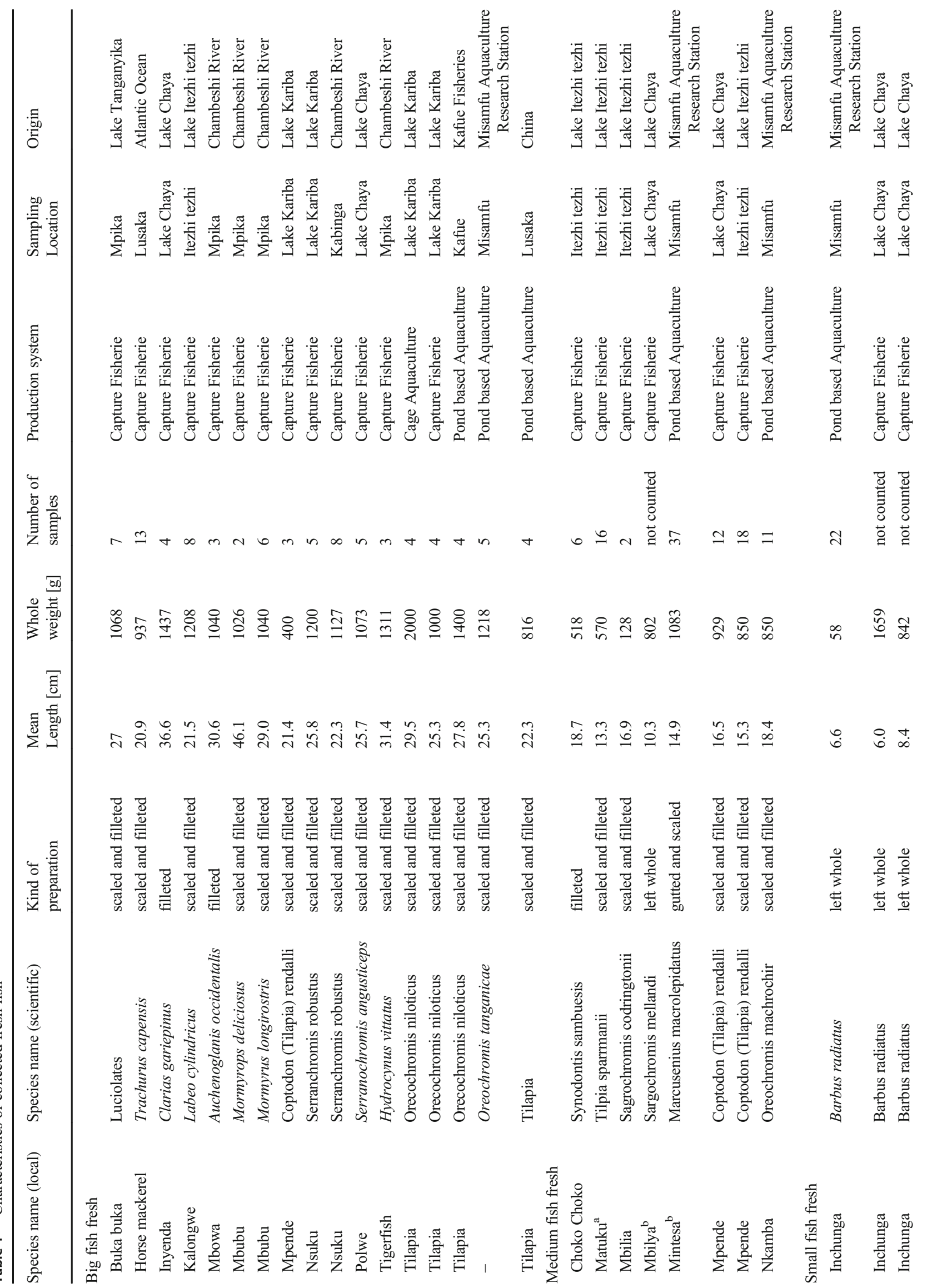




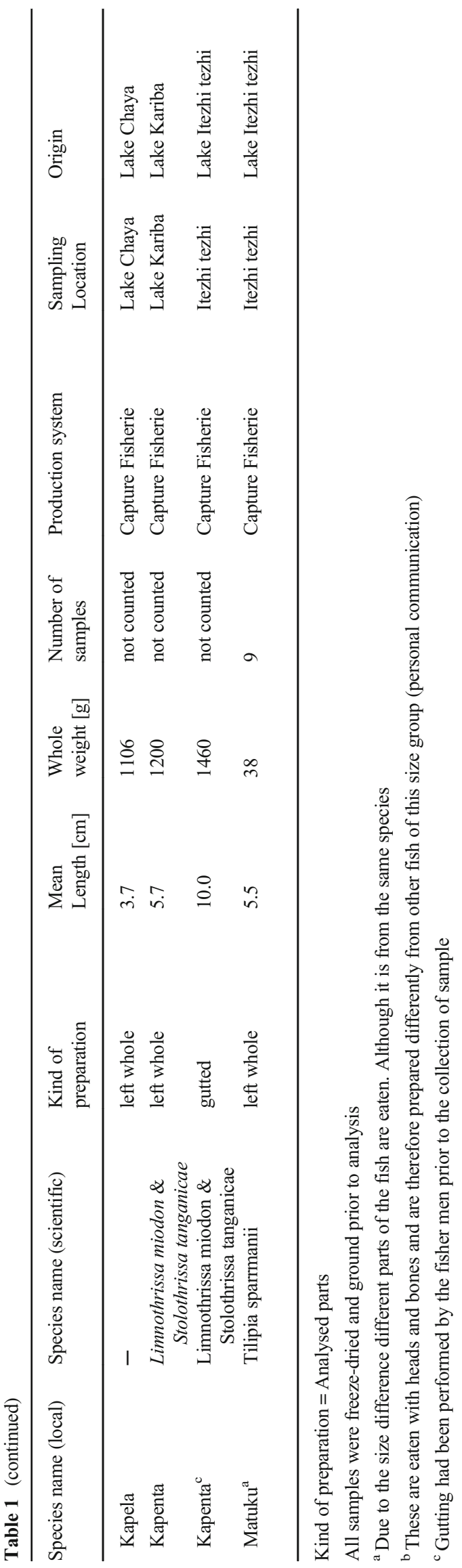

2014). Although small fish species have also been reported to be rich sources of vitamin A (Roos et al. 2002, 2007), vitamin A in fresh water species is mainly 3,4-dehydroretinol. The conversion rate of this compound is however unclear in the human body (Kawarazuka and Béné 2011). It was therefore decided to focus on B-vitamins. Achieving these objectives should help to better inform Zambian policy-makers and NGOs working in Zambia, when designing fish-based programs tackling malnutrition, choosing species to promote for consumption, and perhaps to enhance aquaculture production.

\section{Methods}

\subsection{Collection of fish samples for analysis}

Fish were sampled between July and August 2016 at six different sample sites: Siavonga, Kafue, Kasama, Mpika, Lake Itezhi tezhi and Lusaka (Fig. 1). Kafue and Lake Itezhi tezhi are major fishing sites themselves, while Siavonga and Mpika are located close to Lake Kariba or Lake Bangweulu respectively, which are major fishing sites too (Musumali et al. 2009). Kasama is the capital of the Northern Province and thus a large market for fish from the region. Together with Siavonga and Kafue it is also a location where fish from aquaculture can be easily obtained (Genschick et al. 2017). Lusaka one of the main centres for trade with these fish (Musumali et al. 2009), where imported fish species can be easily obtained was chosen too. Fish was purchased at the sampling sites directly from fishermen or local markets and in the case of Lusaka frozen from a local supermarket. Fish were first grouped according to species, then subdivided according to processing status and then further divided into large $(>20 \mathrm{~cm})$, medium $(10-20 \mathrm{~cm})$ and small fish $(<10 \mathrm{~cm})$, as the size of a fish is usually an indicator of what parts of it are consumed (Tables 1 and 2). Therefore 65 samples, consisting of approximately 40 different species were collected. The exact number of species was hard to determine as many processed fish were sold as a mix, being almost indistinguishable from one another and therefore treated as one sample batch (Table 2). About half the samples were fresh fish, of which large fish species were the biggest group. The other half of the samples consisted of approximately equal amounts of smoked or sun-dried fish. Smoked fish were usually medium sized, while all sun-dried samples were small fish species. Depending on the size of the fish and the availability at the sampling site, the number of fish composing one pooled sample as well as the total weight of the sample could strongly vary. This was especially true for small processed fish as these had to be sometimes sorted from a larger batch of mixed Kasepa therefore leading to a very low amount of this specific fish. Detailed descriptions for each sample are provided in Tables 1 and 2 . 


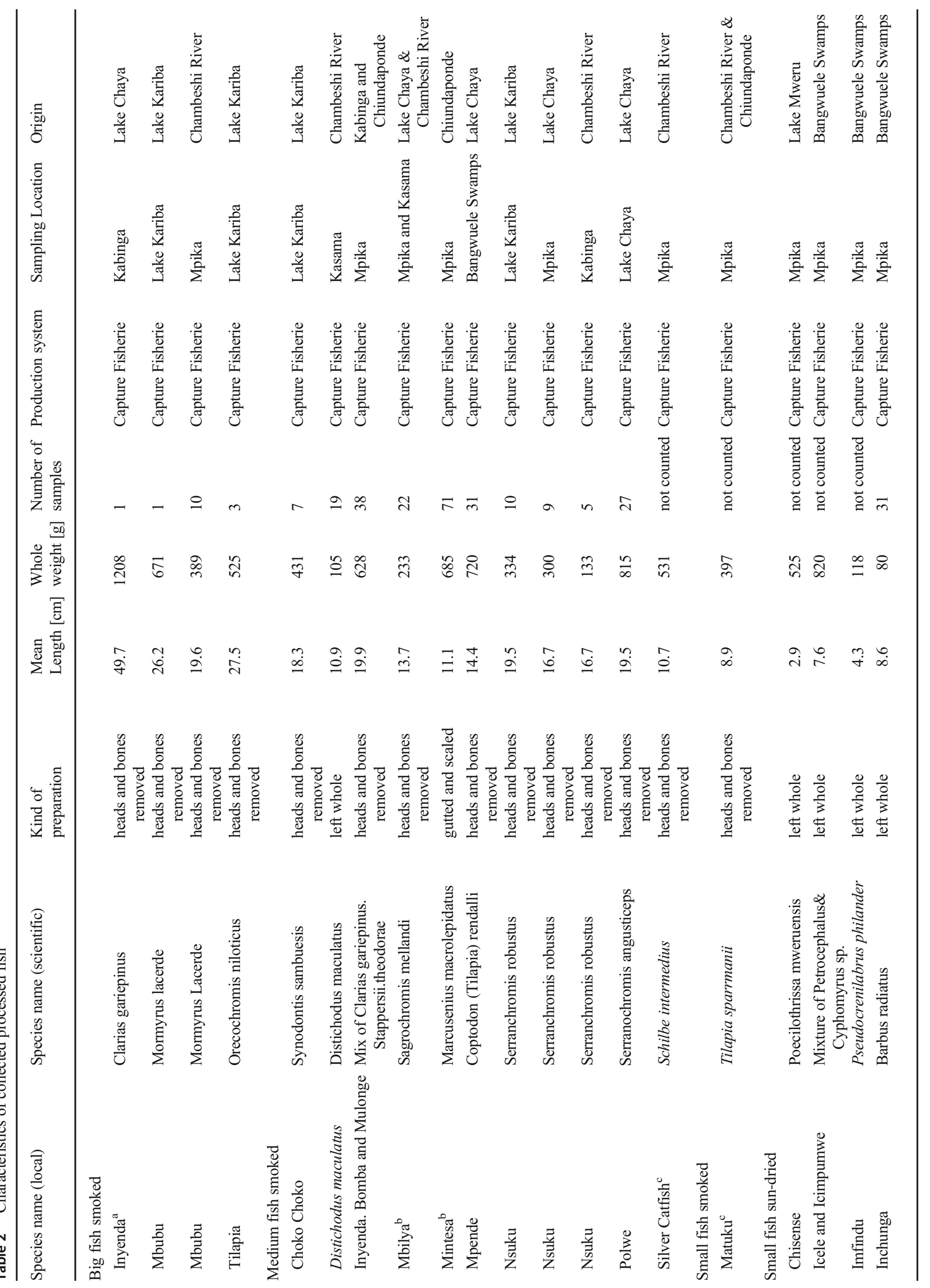




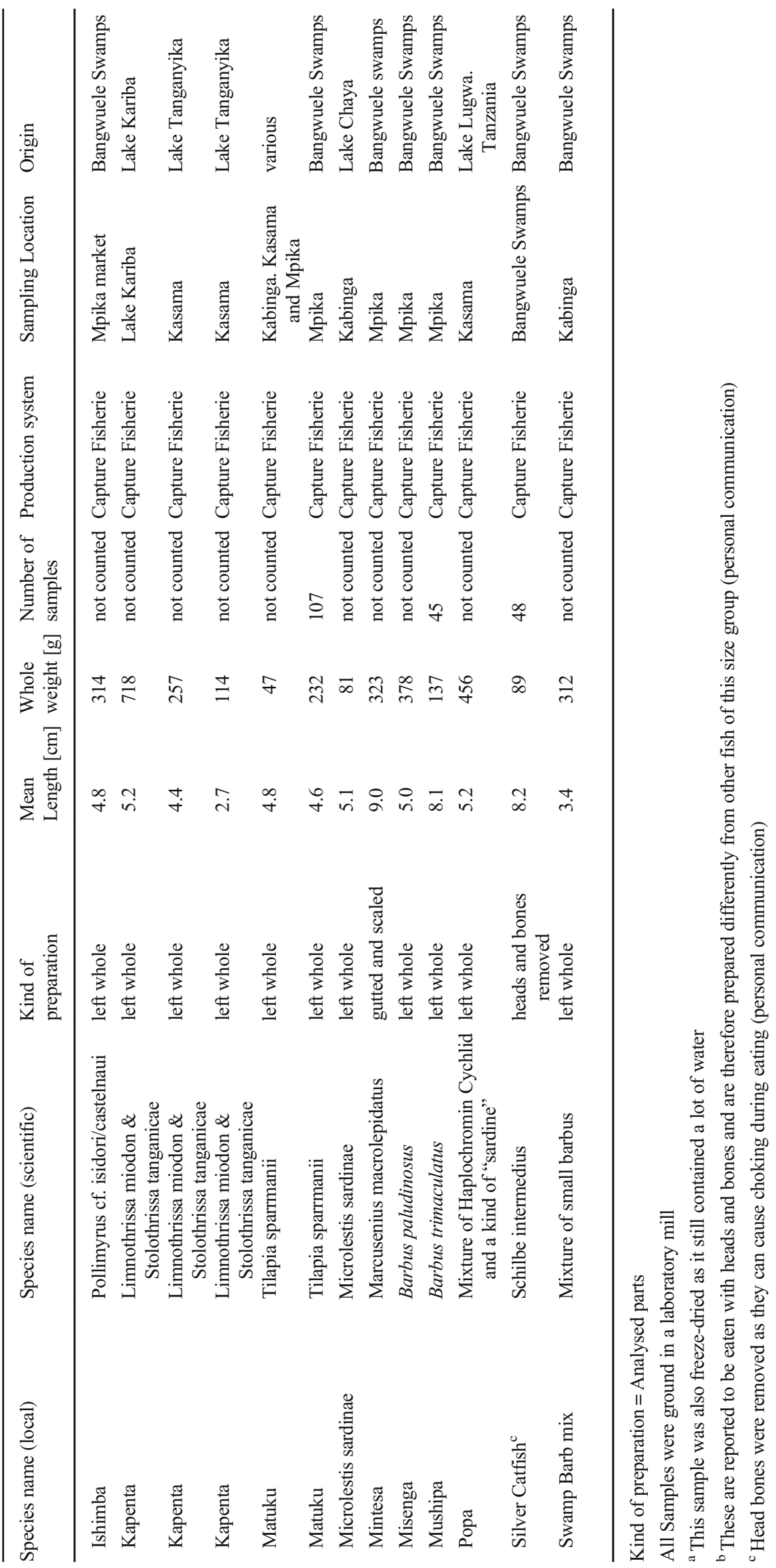




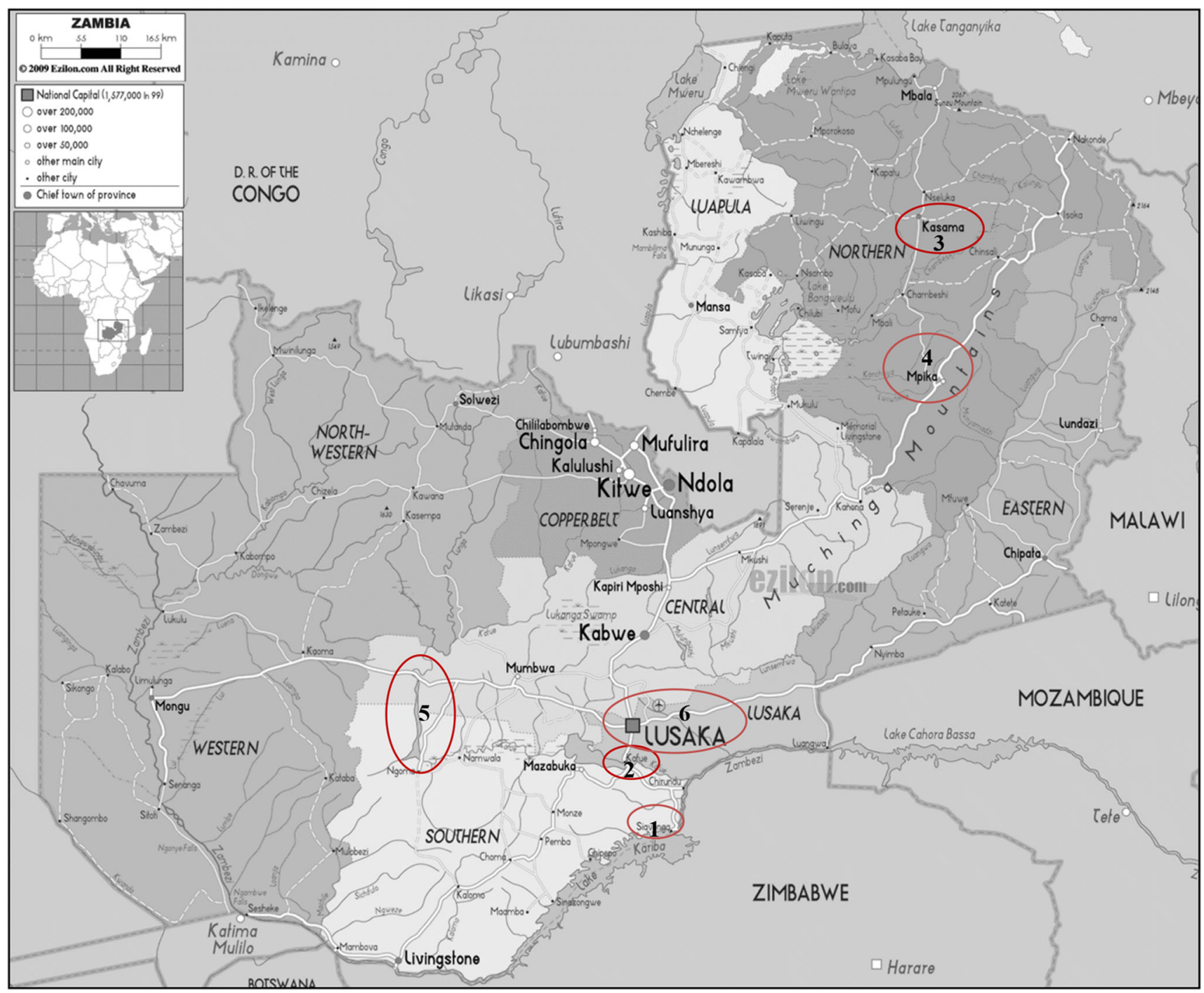

Fig. 1 Fish sampling sites in Zambia. Siavonga, Kafue, Kasama, Mpika, Lake Itezhi tezhi, Lusaka. Map adapted from (Ezilon Maps 2009)

\subsection{Preparation of fish prior to chemical analysis}

Tables 1 and 2 provide an overview of how each fish was prepared prior to analysis. A more detailed description on the preparation procedures can be found in Appendix 1, page 2.

\subsection{Chemical analysis of (micro)nutrient composition}

Descriptions off the chemical analyses conducted can be found in Appendix 2. This includes the analysis of proximate (protein, fat, water) and fatty acid composition; the analysis of vitamin (riboflavin, niacin, folate and vitamin B12) and dietary mineral composition (calcium, iron, zinc, potassium, magnesium and selenium), and references for methods used.

\subsection{Calculation of nutrient contents and contribution to the RDI}

Results for fresh fish are reported on a fresh weight basis, while results for smoked and sun-dried fish are reported containing their respective residual water content and are therefore usually presented together under the term processed fish. All results are expressed as content per $100 \mathrm{~g}$ edible portion (EP), with the exception: of fatty acid composition (expressed in percent of total fat content). The contribution of fish to the Recommended Daily Intake (RDI) for each nutrient was calculated for women and children $\geq 4$ years, as well as for children between 1 and 3 years, using the values recommended by the Food and Drug Administration (FDA) (2016). A sample was defined as a good source of a specific nutrient, if it contained 10\%-19\% of this nutrient per $100 \mathrm{~g} \mathrm{EP}$, while a sample providing 
more than $20 \%$ of a specific nutrient per $100 \mathrm{~g}$ EP was considered an excellent source for this nutrient.

The aim of the study was to provide a quantitative description of nutritional values across many fish species, origins and types of processing. The data reported here are therefore descriptive with no statistical analysis, except the calculation of mean values for duplicate and triplicate analyses and standard deviations for triplicate analyses. We recognise that several sources of variation exist, including species, processing, the originating water body and seasonality which can have a strong influence on the nutrient composition (Kawarazuka and Béné 2011; Bogard et al. 2015).

\section{Results}

\subsection{Proximate composition (protein, fat and water)}

Contents of protein, fat and water are reported in Table 3. The fresh fish samples showed an overall uniform protein content ranging from $13.13 \mathrm{~g} / 100 \mathrm{~g}$ EP (Kalongwe) to $23.20 \mathrm{~g} / 100 \mathrm{~g}$ EP (Buka buka), with a mean value of $17.38 \pm 2.29 \mathrm{~g} / 100 \mathrm{~g}$ EP. The processed fish protein content ranged from $27.79 \mathrm{~g} /$ $100 \mathrm{~g}$ EP (Inyenda) to $82.40 \mathrm{~g} / 100 \mathrm{~g} \mathrm{EP}$ (Nsuku). Compared to the protein content, the fat content of fresh fish was more variable and ranged from $0.79 \mathrm{~g} / 100 \mathrm{~g} \mathrm{EP}$ (Polwe) to $14.40 \mathrm{~g} /$ $100 \mathrm{~g}$ EP (Choko choko), with a mean value of $3.52 \pm 3.06 \mathrm{~g} /$ $100 \mathrm{~g}$ EP. The medium fish had the highest mean fat content of all fresh samples due to a sample of Choko choko, although, small fresh fish showed generally higher fat contents when looking at single species. Large fresh fish species usually had the lowest amount of fat overall. Large variation in fat content was also found among samples from the same species. Tilapias from aquaculture were found to contain more fat (5.70-6.46 g/100 g EP) than wild Tilapias $(1.54 \mathrm{~g} / 100 \mathrm{~g}$ EP). The fat content of processed samples varied considerably too, ranging from $2.79 \mathrm{~g} / 100 \mathrm{~g} \mathrm{EP}$ (Inyenda) to $35.90 \mathrm{~g} / 100 \mathrm{~g}$ EP (Icele and Icimpumwe), with a mean value of $15.65 \pm$ $7.40 \mathrm{~g} / 100 \mathrm{~g}$ EP. Compared to fresh fish, processed small fish showed the highest mean fat content. Water content of fresh fish was found to be very similar among the different species, ranging from $65.34 \mathrm{~g} / 100 \mathrm{~g}$ EP (Inchunga) to $83.38 \mathrm{~g} / 100 \mathrm{~g}$ EP $(M b u b u)$, with a mean water content $77.23 \pm 4.69 \mathrm{~g} / 100 \mathrm{~g}$ EP. The water content of processed fish was mostly low, ranging from $5.79 \mathrm{~g} / 100 \mathrm{~g}$ EP (Mintesa) to up to $22.37 \mathrm{~g}$ / $100 \mathrm{~g}$ (Polwe), except for smoked Inyenda (66.80 g water per $100 \mathrm{~g} \mathrm{EP})$.

\subsection{Fatty acid composition}

Samples were analysed for 37 different fatty acids. Only results for 4 selected fatty acids are reported in this section: linoleic acid (C 18:2), $\alpha$-linolenic acid (C 18:3 $\omega-3$ ), eicosapentaenoic acid (EPA) (C 20:5) and docosahexaenoic acid (DHA) (C 22:6). These are essential fatty acids, or have a low synthesis rate in humans (EPA and DHA), and must be supplied in the diet. There is further interest in EPA and DHA, as fish and fish products are their main dietary source (Swanson et al. 2012). Detailed values for the chosen fatty acids are presented in Table 4.

The percentage of linoleic acid in fresh fish ranged from $1.04 \%$ (Horse mackerel) to $19.88 \%$ (Nkamba), while the percentage of $\alpha$-linolenic acid ranged from $0.31 \%$ (Horse mackerel) to $4.86 \%$ (Kalongwe). The highest percentages of linoleic acid, which is commonly found in plants, were found in large, or medium-large herbivorous fish such as Tilapia or Nkamba. The percentage of EPA ranged from $0.05 \%$ (Tilapia) to $2.79 \%$ (Kapenta) and the percentage of DHA ranged from $0.16 \%$ (Choko choko) to $13.39 \%$ (Nsuku). Levels of linoleic acid in processed fish ranged from $0.98 \%$ (Popa) to $12.76 \%$ (Mushipa). In general processed samples showed a lower percentage of linoleic acid than fish of the same species. Smoked fish mostly showed a higher percentage of the considered fatty acids than sun-dried ones. The percentage of EPA ranged from $0.09 \%$ (Microlestis sardinae) to $5.66 \%$ (Kapenta), while the percentage of DHA ranged from $0.02 \%(N s u k u)$ to $8.55 \%$ (Chisense). Overall small processed fish, especially Kapenta and Chisense showed higher contents of EPA and DHA, compared to large and medium processed fish, with some exceptions.

\subsection{Vitamin composition (riboflavin, niacin, folate and vitamin B12)}

Values for all analysed vitamins are presented in detail in Table 5. In samples of fresh fish, contents of riboflavin ranged from $0.004 \mathrm{mg} / 100 \mathrm{~g} \mathrm{EP} \mathrm{(Tigerfish)} \mathrm{to} 0.36 \mathrm{mg} / 100 \mathrm{~g} \mathrm{EP}$ (Mintesa) with a mean value of $0.11 \pm 0.06 \mathrm{mg} / 100 \mathrm{~g}$ edible portion. Niacin contents ranged from $0.53 \mathrm{mg} / 100 \mathrm{~g} \mathrm{EP}$ (Mbubu) to $7.63 \mathrm{mg} / 100 \mathrm{~g} \mathrm{EP}$ (Buka buka), with a mean value of $2.78 \mathrm{mg} \pm 1.41 \mathrm{mg} / 100 \mathrm{~g} \mathrm{EP}$, while folate contents ranged from $5.64 \mu \mathrm{g} / 100 \mathrm{~g} \mathrm{EP}(M b u b u)$ to $27.07 \mu \mathrm{g} / 100 \mathrm{~g} \mathrm{EP}$ (Mbilya), with a mean content of $13.12 \mu \mathrm{g} \pm 5.67 \mu \mathrm{g} / 100 \mathrm{~g}$ EP. Vitamin B12 contents ranged from $0.62 \mu \mathrm{g} / 100 \mathrm{~g}$ EP (Mbubu) to $14.91 \mu \mathrm{g} / 100 \mathrm{~g}$ (Inchunga), with a mean content of $4.08 \pm 3.78 \mu \mathrm{g} / 100 \mathrm{~g}$ EP. The mean content of riboflavin was highest in medium fish species, almost twofold higher than the mean of large and small fish that had similar riboflavin contents. Interestingly some of the highest riboflavin contents were found in fish which belonged to the same species (e.g., Tilapia and Matuku), or to related species. Matuku was especially interesting, as its two fresh samples belonged to different size groups and were prepared differently prior to analysis (Table 1). The highest niacin contents were also usually found in large and medium fish, such as Buka buka and Horse mackerel, in which only the flesh and skin are 
Table 3 Proximate composition of fresh and processed fish

\begin{tabular}{|c|c|c|c|c|c|}
\hline \multirow[t]{2}{*}{ Species name (local) } & \multirow[t]{2}{*}{ Species name (scientific) } & \multirow[t]{2}{*}{ Kind of preparation } & \multicolumn{3}{|c|}{ Content per $100 \mathrm{~g}$ edible portion } \\
\hline & & & Protein $[\mathrm{g}]$ & Fat $[\mathrm{g}]$ & Water $[\mathrm{g}]$ \\
\hline \multicolumn{6}{|l|}{ Big fish fresh } \\
\hline Buka buka & Luciolates & scaled and filleted & 23.20 & 2.37 & 73.67 \\
\hline Horse mackerel & Trachurus capensis & scaled and filleted & 19.74 & 1.24 & 77.69 \\
\hline Inyenda & Clarias gariepinus & washed and filleted & 16.47 & 1.43 & 81.40 \\
\hline Kalongwe & Labeo cylindricus & scaled and filleted & 13.13 & 3.20 & 82.58 \\
\hline Mbowa & Auchenoglanis occidentalis & washed and filleted & 17.03 & 1.11 & 81.51 \\
\hline Mbubu & Mormyrops deliciosus & scaled and filleted & 16.30 & 3.41 & 79.95 \\
\hline Mbubu & Mormyrus longirostris & scaled and filleted & 13.55 & 2.45 & 83.38 \\
\hline Mpende & Coptodon (Tilapia) rendalli & scaled and filleted & 16.49 & 3.76 & 79.35 \\
\hline Nsuku & Serranchromis robustus & scaled and filleted & 16.38 & 0.93 & 82.79 \\
\hline Nsuku & Serranchromis robustus & scaled and filleted & 17.78 & 1.22 & 80.68 \\
\hline Polwe & Serranochromis angusticeps & scaled and filleted & 17.68 & 0.79 & 80.86 \\
\hline Tigerfish & Hydrocynus vittatus & scaled and filleted & 17.97 & 6.49 & 75.38 \\
\hline Tilapia & Orecochromis niloticus & scaled and filleted & 19.23 & 6.46 & 73.91 \\
\hline Tilapia & Orecochromis niloticus & scaled and filleted & 17.11 & 1.54 & 80.90 \\
\hline Tilapia & Orecochromis niloticus & scaled and filleted & 21.81 & 5.70 & 72.17 \\
\hline- & Oreochromis tanganicae & scaled and filleted & 16.78 & 2.52 & 78.98 \\
\hline Tilapia & Tilapia & scaled and filleted & 17.06 & 2.07 & 80.61 \\
\hline \multicolumn{6}{|l|}{ Medium fish fresh } \\
\hline Choko Choko & Synodontis sambuesis & washed and filleted & 16.49 & 14.40 & 67.94 \\
\hline Matuku & Tilpia sparrmanii & scaled and filleted & - & - & 80.57 \\
\hline Mbilia & Sagrochromis codringtonii & scaled and filleted & - & - & 77.68 \\
\hline Mbilya & Sargochromis mellandi & washed and left whole & 18.01 & 4.22 & 73.86 \\
\hline Mintesa & Marcusenius macrolepidatus & gutted and scaled & 17.06 & 8.13 & 71.93 \\
\hline Mpende & Coptodon (Tilapia) rendalli & scaled and filleted & 19.65 & 1.24 & 78.56 \\
\hline Mpende & Coptodon (Tilapia) rendalli & scaled and filleted & 17.17 & 1.29 & 80.94 \\
\hline Nkamba & Oreochromis machrochir & scaled and filleted & 18.40 & 1.44 & 79.28 \\
\hline \multicolumn{6}{|l|}{ Small fish fresh } \\
\hline Inchunga & Barbus radiatus & washed and left whole & - & - & 77.01 \\
\hline Inchunga & Barbus radiatus & washed and left whole & 17.29 & 4.38 & 73.71 \\
\hline Inchunga & Barbus radiatus & washed and left whole & 21.81 & 8.62 & 65.34 \\
\hline Kapela & - & washed and left whole & 21.75 & 3.83 & 70.69 \\
\hline Kapenta & Limnothrissa miodon \& Stolothrissa tanganicae & washed and left whole & 16.45 & 1.77 & 77.63 \\
\hline Kapenta & Limnothrissa miodon \& Stolothrissa tanganicae & washed and gutted & 17.31 & 2.59 & 76.68 \\
\hline Matuku & Tilipia sparrmanii & washed and left whole & - & - & 77.01 \\
\hline \multicolumn{6}{|l|}{ Big fish smoked } \\
\hline Inyenda & Clarias gariepinus & heads and bones removed & 29.79 & 2.79 & 66.80 \\
\hline Mbubu & Mormyrus lacerde & heads and bones removed & 64.10 & 22.80 & 9.84 \\
\hline Mbubu & Mormyrus Lacerde & heads and bones removed & 76.70 & 12.70 & 7.61 \\
\hline Tilapia & Orecochromis niloticus & heads and bones removed & 70.40 & 10.80 & 17.39 \\
\hline \multicolumn{6}{|l|}{ Medium fish smoked } \\
\hline Choko Choko & Synodontis sambuesis & heads and bones removed & 62.90 & 28.00 & 8.23 \\
\hline Distichodus maculatus & Distichodus maculatus & left whole & 63.20 & 17.50 & 8.17 \\
\hline Inyenda. Bomba and Mulonge & Mix of Clarias gariepinus. Stappersii.theodorae & heads and bones removed & 67.90 & 19.10 & 9.09 \\
\hline Mbilya & Sagrochromis mellandi & heads and bones removed & 70.40 & 15.60 & 12.04 \\
\hline Mintesa & Marcusenius macrolepidatus & gutted and scaled & 59.60 & 26.10 & 5.79 \\
\hline Mpende & Coptodon (Tilapia) rendalli & heads and bones removed & 67.30 & 10.50 & 19.7 \\
\hline
\end{tabular}


Table 3 (continued)

\begin{tabular}{|c|c|c|c|c|c|}
\hline \multirow[t]{2}{*}{ Species name (local) } & \multirow[t]{2}{*}{ Species name (scientific) } & \multirow[t]{2}{*}{ Kind of preparation } & \multicolumn{3}{|c|}{ Content per $100 \mathrm{~g}$ edible portion } \\
\hline & & & Protein $[\mathrm{g}]$ & Fat $[\mathrm{g}]$ & Water $[\mathrm{g}]$ \\
\hline Nsuku & Serranchromis robustus & heads and bones removed & 82.40 & 4.90 & 9.95 \\
\hline Nsuku & Serranchromis robustus & heads and bones removed & 69.10 & 5.10 & 21.17 \\
\hline Nsuku & Serranchromis robustus & heads and bones removed & 76.90 & 6.80 & 13.46 \\
\hline Polwe & Serranochromis angusticeps & heads and bones removed & 70.60 & 6.30 & 22.37 \\
\hline Silver Catfish & Schilbe intermedius & heads and bones removed & 62.00 & 20.80 & 13.72 \\
\hline \multicolumn{6}{|l|}{ Small fish smoked } \\
\hline Matuku & Tilapia sparrmanii & heads and bones removed & 73.20 & 13.20 & 8.37 \\
\hline \multicolumn{6}{|l|}{ Small fish sun-dried } \\
\hline Chisense & Poecilothrissa mweruensis & left whole & 67.90 & 12.70 & 7.34 \\
\hline Icele and Icimpumwe & Mixture of Petrocephalus\&Cyphomyrus sp. & left whole & 47.40 & 35.90 & 7.45 \\
\hline Imfindu & Pseudocrenilabrus philander & left whole & 57.00 & 17.30 & 8.69 \\
\hline Inchunga & Barbus radiatus & left whole & 57.50 & 17.70 & 9.56 \\
\hline Ishimba & Pollimyrus cf. isidori/castelnaui & left whole & 60.20 & 18.00 & 9.5 \\
\hline Kapenta & Limnothrissa miodon \& Stolothrissa tanganicae & left whole & 67.50 & 11.00 & 9.00 \\
\hline Kapenta & Limnothrissa miodon \& Stolothrissa tanganicae & left whole & 62.10 & 14.40 & 11.21 \\
\hline Kapenta & Limnothrissa miodon \& Stolothrissa tanganicae & left whole & 67.30 & 12.30 & 9.33 \\
\hline Matuku & Tilapia sparrmanii & left whole & 59.70 & 14.00 & 9.01 \\
\hline Matuku & Tilapia sparrmanii & left whole & 57.30 & 19.70 & 7.71 \\
\hline Microlestis sardinae & Microlestis sardinae & left whole & 53.60 & 23.00 & 7.8 \\
\hline Mintesa & Marcusenius macrolepidatus & gutted and scaled & 66.00 & 12.10 & 10.54 \\
\hline Misenga & Barbus paludinosus & left whole & 53.00 & 25.10 & 8.96 \\
\hline Mushipa & Barbus trimaculatus & left whole & 56.20 & 23.60 & 8.89 \\
\hline Popa & $\begin{array}{l}\text { Mixture of Haplochromin Cychlid } \\
\text { and a kind of "sardine" }\end{array}$ & left whole & 59.60 & 9.50 & 10.38 \\
\hline Silver Catfish & Schilbe intermedius & heads and bones removed & 62.50 & 16.90 & 9.12 \\
\hline Swamp Barb mix & Mixture of small barbus & left whole & 64.80 & 10.20 & 8.75 \\
\hline
\end{tabular}

$n=2$

Kind of preparation is equal to analysed parts

commonly consumed. Yet many large fish contained much lower levels of niacin and samples of Kapenta contained similar or higher amounts of niacin than many samples of large fish $(2.97 \& 3.62 \mathrm{mg} / 100 \mathrm{~g} \mathrm{EP})$. In the case of folate, the highest contents were generally found in small and smaller medium fish such as Mbilya, Inchunga and Kapela, although there were some exceptions (Polwe). Thiswas also true for vitamin B12, as only the sample of Horse mackerel contained similar amounts of vitamin B12 as samples found in the small fish group.

In samples of processed fish, contents of riboflavin ranged from 0.10 (Choko choko) to $1.29 \mathrm{mg} / 100 \mathrm{~g} \mathrm{EP}$ (Matuku), with a mean value of $0.47 \pm 0.37 \mathrm{mg} / 100 \mathrm{~g}$ EP. Niacin contents ranged from $3.72 \mathrm{mg} / 100 \mathrm{~g}$ EP (Icele and Icimpumwe) to $20.70 \mathrm{mg} / 100 \mathrm{~g}$ EP (Kapenta), with a mean value of $7.79 \mathrm{mg} \pm 4.39 \mathrm{mg} / 100 \mathrm{~g}$ EP. Folate content ranged from $12.80 \mu \mathrm{g} / 100 \mathrm{~g}$ EP (Tilapia) to
$125.00 \mu \mathrm{g} / 100 \mathrm{~g}$ EP (Silver Catfish), with a mean content of $50.17 \mu \mathrm{g} \pm 22.80 \mu \mathrm{g} / 100 \mathrm{~g}$ EP, while vitamin B12 contents ranged from $3.31 \mu \mathrm{g} / 100 \mathrm{~g}$ EP $(M b u b u)$ to $64.20 \mu \mathrm{g} / 100 \mathrm{~g}$ EP (Popa), with a mean value of $24.95 \pm 18.00 \mu \mathrm{g} / 100 \mathrm{~g}$ EP. The above findings for fresh fish samples were largely corroborated by the results from processed ones. The processed fish, which showed the highest riboflavin contents, belonged to the same species, Mintesa, Matuku and Mbilya. These were the same species that contained the highest amounts of riboflavin in fresh samples. Large and bigger medium fish,in which only the flesh and skin had been analysed, contained generally higher amounts of niacin, again with the exception of Kapenta, which in fact contained the highest amounts of niacin in all processed samples $(17.30,20.20$ and $20.70 \mathrm{mg} / 100 \mathrm{~g} \mathrm{EP})$. Small and smaller medium fish usually contain the highest amounts of folate. Large fish 
Table 4 Fatty acid composition of fresh and processed fish samples. Fresh fish are presented on a fresh weight basis. Processed fish are presented with their residual water content

\begin{tabular}{|c|c|c|c|c|c|c|}
\hline Species name (local) & Species name (scientific) & Kind of preparation & $\begin{array}{l}\text { Linoleic } \\
\text { acid [\%] }\end{array}$ & $\begin{array}{l}\alpha \text {-Linolenic } \\
\text { acid }[\%]\end{array}$ & $\begin{array}{l}\mathrm{EPA} \\
{[\%]}\end{array}$ & $\begin{array}{l}\text { DHA } \\
{[\%]}\end{array}$ \\
\hline \multicolumn{7}{|l|}{ Big fish fresh } \\
\hline Buka buka & Luciolates & scaled and filleted & 1.67 & 0.87 & 0.67 & 2.55 \\
\hline Horse mackerel & Trachurus capensis & scaled and filleted & 1.04 & 0.31 & 2.28 & 7.64 \\
\hline Inyenda & Clarias gariepinus & washed and filleted & 9.91 & 2.52 & 0.44 & 2.87 \\
\hline Kalongwe & Labeo cylindricus & scaled and filleted & 2.75 & 4.86 & 1.69 & 1.37 \\
\hline Mbowa & Auchenoglanis occidentalis & washed and filleted & 7.09 & 1.99 & 1.5 & 2.25 \\
\hline Mbubu & Mormyrops deliciosus & scaled and filleted & 4.51 & 1.12 & 0.16 & 2.9 \\
\hline Mbubu & Mormyrus longirostris & scaled and filleted & 4.1 & 1.12 & 1.63 & 2.4 \\
\hline Mpende & Coptodon (Tilapia) rendalli & scaled and filleted & 16.17 & 0.87 & 0.2 & 0.98 \\
\hline Nsuku & Serranchromis robustus & scaled and filleted & 4.56 & 2.03 & 0.61 & 13.39 \\
\hline Nsuku & Serranchromis robustus & scaled and filleted & 9.47 & 3.41 & 0.35 & 3.96 \\
\hline Polwe & Serranochromis angusticeps & scaled and filleted & 5.34 & 1.13 & 0.21 & 2.74 \\
\hline Tigerfish & Hydrocynus vittatus & scaled and filleted & 7.01 & 4.18 & 0.39 & 3.04 \\
\hline Tilapia & Orecochromis niloticus & scaled and filleted & 15.64 & 1.02 & 0.05 & 0.41 \\
\hline Tilapia & Orecochromis niloticus & scaled and filleted & 15.16 & 1 & 0.3 & 2.74 \\
\hline Tilapia & Orecochromis niloticus & scaled and filleted & 18.4 & 1.41 & 0.14 & 0.89 \\
\hline- & Oreochromis tanganicae & scaled and filleted & 15.56 & 1.53 & 0.14 & 1.02 \\
\hline Tilapia & Tilapia & scaled and filleted & 14.22 & 1.39 & 0.15 & 0.86 \\
\hline \multicolumn{7}{|l|}{ Medium fish fresh } \\
\hline Choko Choko & Synodontis sambuesis & washed and filleted & 2.4 & 1.11 & 0.24 & 0.16 \\
\hline Matuku & Tilpia sparrmanii & scaled and filleted & - & - & - & - \\
\hline Mbilia & Sagrochromis codringtonii & scaled and filleted & - & - & - & - \\
\hline Mbilya & Sargochromis mellandi & washed and left whole & 8.94 & 2.6 & 0.81 & 2.54 \\
\hline Mintesa & Marcusenius macrolepidatus & gutted and scaled & 8.78 & 2.52 & 0.58 & 1.06 \\
\hline Mpende & Coptodon (Tilapia) rendalli & scaled and filleted & 13.42 & 4.06 & 0.58 & 3.04 \\
\hline Mpende & Coptodon (Tilapia) rendalli & scaled and filleted & 7.64 & 1.31 & 0.1 & 0.44 \\
\hline Nkamba & Oreochromis machrochir & scaled and filleted & 19.88 & 1.69 & 0.24 & 2.32 \\
\hline \multicolumn{7}{|l|}{ Small fish fresh } \\
\hline Inchunga & Barbus radiatus & washed and left whole & - & - & - & - \\
\hline Inchunga & Barbus radiatus & washed and left whole & 3.21 & 1.63 & 0.22 & 0.22 \\
\hline Inchunga & Barbus radiatus & washed and left whole & 3.56 & 2.24 & 0.71 & 1.33 \\
\hline Kapela & - & washed and left whole & 2.32 & 1.57 & 1.18 & 3.08 \\
\hline Kapenta & $\begin{array}{l}\text { Limnothrissa miodon \& } \\
\text { Stolothrissa tanganicae }\end{array}$ & washed and left whole & 4.39 & 2.35 & 2.79 & 7.84 \\
\hline Kapenta & $\begin{array}{l}\text { Limnothrissa miodon \& } \\
\text { Stolothrissa tanganicae }\end{array}$ & washed and gutted & 5.07 & 3.08 & 1.57 & 1.72 \\
\hline Matuku & Tilipia sparrmanii & washed and left whole & - & - & - & - \\
\hline \multicolumn{7}{|l|}{ Big fish smoked } \\
\hline Inyenda & Clarias gariepinus & heads and bones removed & 6.76 & 1.48 & 0.24 & 2.66 \\
\hline Mbubu & Mormyrus lacerde & heads and bones removed & 5.17 & 2.68 & 0.68 & 6.9 \\
\hline Mbubu & Mormyrus Lacerde & heads and bones removed & 4.44 & 1.3 & 0.12 & 0.85 \\
\hline Tilapia & Orecochromis niloticus & heads and bones removed & 3.34 & 3.03 & 0.32 & 1.31 \\
\hline \multicolumn{7}{|l|}{ Medium fish smoked } \\
\hline Choko Choko & Synodontis sambuesis & heads and bones removed & 5.53 & 2.81 & 0.9 & 2.55 \\
\hline Distichodus maculatus & Distichodus maculatus & left whole & 10.75 & 3.92 & 0.13 & 0.21 \\
\hline Inyenda. Bomba and Mulonge & $\begin{array}{l}\text { Mix of Clarias gariepinus. } \\
\text { Stappersii.theodorae }\end{array}$ & heads and bones removed & 9.71 & 3.32 & 1.14 & 1.95 \\
\hline Mbilya & Sagrochromis mellandi & heads and bones removed & 13.6 & 1.09 & 0.22 & 0.82 \\
\hline
\end{tabular}


Table 4 (continued)

\begin{tabular}{|c|c|c|c|c|c|c|}
\hline Species name (local) & Species name (scientific) & Kind of preparation & $\begin{array}{l}\text { Linoleic } \\
\text { acid [\%] }\end{array}$ & $\begin{array}{l}\alpha \text {-Linolenic } \\
\text { acid }[\%]\end{array}$ & $\begin{array}{l}\text { EPA } \\
{[\%]}\end{array}$ & $\begin{array}{l}\text { DHA } \\
{[\%]}\end{array}$ \\
\hline Mintesa & Marcusenius macrolepidatus & gutted and scaled & 4 & 1.07 & 0.31 & 0.44 \\
\hline Mpende & Coptodon (Tilapia) rendalli & heads and bones removed & 7.2 & 1.37 & 0.04 & 0.12 \\
\hline Nsuku & Serranchromis robustus & heads and bones removed & 5.93 & 1.87 & 0.34 & 6.23 \\
\hline Nsuku & Serranchromis robustus & heads and bones removed & 5.81 & 1.81 & 0.29 & 0.02 \\
\hline Nsuku & Serranchromis robustus & heads and bones removed & 6.97 & 1.56 & 0.41 & 5.77 \\
\hline Polwe & Serranochromis angusticeps & heads and bones removed & 2.78 & 0.67 & - & 0.73 \\
\hline Silver Catfish & Schilbe intermedius & heads and bones removed & 9.58 & 7.81 & 1.25 & 2.29 \\
\hline \multicolumn{7}{|l|}{ Small fish smoked } \\
\hline Matuku & Tilapia sparrmanii & heads and bones removed & 10.83 & 9.4 & 0.47 & 2.15 \\
\hline \multicolumn{7}{|l|}{ Small fish sun-dried } \\
\hline Chisense & Poecilothrissa mweruensis & left whole & 4.42 & 3.41 & 3.65 & 8.55 \\
\hline Icele and Icimpumwe & $\begin{array}{l}\text { Mixture of Petrocephalus\& } \\
\text { Cyphomyrus sp. }\end{array}$ & left whole & 7.02 & 4.4 & 0.61 & 0.73 \\
\hline Imfindu & Pseudocrenilabrus philander & left whole & 7.99 & 2.7 & 1.28 & 4.4 \\
\hline Inchunga & Barbus radiatus & left whole & 9.86 & 1.68 & 0.84 & 2.02 \\
\hline Ishimba & Pollimyrus cf. isidori/castelnaui & left whole & 6.54 & 1.82 & 1.35 & 2.36 \\
\hline Kapenta & $\begin{array}{l}\text { Limnothrissa miodon \& } \\
\text { Stolothrissa tanganicae }\end{array}$ & left whole & 3.55 & 3.37 & 3.94 & 7.82 \\
\hline Kapenta & $\begin{array}{l}\text { Limnothrissa miodon \& } \\
\text { Stolothrissa tanganicae }\end{array}$ & left whole & 1.08 & 0.84 & 5.66 & 5.4 \\
\hline Kapenta & $\begin{array}{l}\text { Limnothrissa miodon \& } \\
\text { Stolothrissa tanganicae }\end{array}$ & left whole & 2.75 & 1.06 & 4.53 & 5.82 \\
\hline Matuku & Tilapia sparrmanii & left whole & 8.13 & 3.92 & 0.26 & 0.98 \\
\hline Matuku & Tilapia sparrmanii & left whole & 7.07 & 5.23 & 0.45 & 1.89 \\
\hline Microlestis sardinae & Microlestis sardinae & left whole & 3.08 & 0.82 & 0.09 & 0.08 \\
\hline Mintesa & Marcusenius macrolepidatus & gutted and scaled & 7.77 & 3.52 & 0.95 & 2.22 \\
\hline Misenga & Barbus paludinosus & left whole & 12.03 & 1.53 & 0.58 & 0.85 \\
\hline Mushipa & Barbus trimaculatus & left whole & 12.76 & 1.45 & 0.4 & 1.68 \\
\hline Popa & $\begin{array}{l}\text { Mixture of Haplochromin Cychlid } \\
\text { and a kind of "sardine" }\end{array}$ & left whole & 0.98 & 0.81 & 1.45 & 3.3 \\
\hline Silver Catfish & Schilbe intermedius & heads and bones removed & 9.64 & 3.95 & 1.31 & 4.48 \\
\hline Swamp Barb mix & Mixture of small barbus & left whole & 6.79 & 2.44 & 0.6 & 1.69 \\
\hline
\end{tabular}

$\mathrm{n}=2$

Values are expressed as percent of total fat content

such as Polwehowever also contained high amounts. Small and some smaller medium fish such as Distichodus maculatus, Ishimba and Mintesa contain the highest amounts of vitamin B12 found in this study.

\subsection{Mineral composition}

Values for all minerals are presented in Table 6. Only calcium, iron and zinc are presented in greater detail. While the other minerals are indeed interesting for establishing nutrient profiles there is no precise data on deficiencies of these minerals in Zambia (Halimatou et al. 2014). Calcium contents of fresh fish ranged from $10.15 \mathrm{mg} / 100 \mathrm{~g} \mathrm{EP}$ (Inyenda) to $1324.38 \mathrm{mg} / 100 \mathrm{~g}$ EP (Matuku), with a mean value of
$304.88 \pm 447.06 \mathrm{mg} / 100 \mathrm{~g}$ EP. Iron content ranged from $0.20 \mathrm{mg} / 100 \mathrm{~g} \mathrm{EP}$ (Mpende) to 16.06 (Matuku), with a mean value of $1.76 \pm 3.18 \mathrm{mg} / 100 \mathrm{~g}$ EP. Zinc contents ranged from $0.37 \mathrm{mg} / 100 \mathrm{~g}$ EP (Mbubu) to $13.73 \mathrm{mg} / 100 \mathrm{~g}$ EP (Kapela), with a mean value of $1.90 \pm 2.51 \mathrm{mg} / 100 \mathrm{~g}$ EP. Small fish usually contained more of all three minerals compared to large and medium fish. The mean calcium content of small fish was about 32 times as high as the mean calcium content of large fish and 4 times as high as the mean calcium content of medium fish. Mean iron contents of small fish were 13 and 7 times higher, while mean zinc contents of small fish were 7 and 4 times higher, compared to large and medium fish.

Calcium contents of processed fish contents ranged from $15.08 \mathrm{mg} / 100 \mathrm{~g} \mathrm{EP}$ (Inyenda) to $4478.31 \mathrm{mg} / 100 \mathrm{~g} \mathrm{EP}$ 
Table 5 Vitamin composition of fresh and processed fish samples

\begin{tabular}{|c|c|c|c|c|c|c|c|}
\hline \multirow[t]{2}{*}{ Species name (local) } & \multirow[t]{2}{*}{ Species name (scientific) } & \multirow[t]{2}{*}{ Kind of preparation } & \multicolumn{5}{|c|}{ Content per $100 \mathrm{~g}$ edible portion } \\
\hline & & & $\begin{array}{l}\text { Riboflavin } \\
{[\mathrm{mg}]}\end{array}$ & $\begin{array}{l}\text { Niacin } \\
{[\mathrm{mg}]}\end{array}$ & $\begin{array}{l}\text { Folate } \\
{[\mu \mathrm{g}]}\end{array}$ & $\begin{array}{l}\text { Vitamin } \\
\text { B12 }[\mu \mathrm{g}]\end{array}$ & $\begin{array}{l}\text { Water } \\
{[\mathrm{g}]}\end{array}$ \\
\hline \multicolumn{8}{|l|}{ Big fish fresh } \\
\hline Buka buka & Luciolates & scaled and filleted & $0.07 \pm 0.004$ & 7.63 & 13.97 & 5.61 & 73.67 \\
\hline Horse mackerel & Trachurus capensis & scaled and filleted & $0.14 \pm 0.009$ & 5.31 & 8.74 & 9.30 & 77.69 \\
\hline Inyenda & Clarias gariepinus & washed and filleted & $0.07 \pm 0.007$ & 2.88 & 20.67 & 3.94 & 81.4 \\
\hline Kalongwe & Labeo cylindricus & scaled and filleted & $0.07 \pm 0.005$ & 2.16 & 5.82 & 4.44 & 82.58 \\
\hline Mbowa & Auchenoglanis occidentalis & washed and filleted & $0.05 \pm 0.009$ & 3.14 & 19.16 & 2.52 & 81.51 \\
\hline Mbubu & Mormyrops deliciosus & scaled and filleted & $0.06 \pm 0.010$ & 0.94 & 18.43 & 0.62 & 79.95 \\
\hline Mbubu & Mormyrus longirostris & scaled and filleted & $0.05 \pm 0.003$ & 0.53 & 5.64 & 2.62 & 83.38 \\
\hline Mpende & Coptodon (Tilapia) rendalli & scaled and filleted & $0.06 \pm 0.013$ & - & - & - & 79.35 \\
\hline Nsuku & Serranchromis robustus & scaled and filleted & $0.08 \pm 0.011$ & 1.79 & 9.48 & 1.42 & 82.79 \\
\hline Nsuku & Serranchromis robustus & scaled and filleted & $0.09 \pm 0.017$ & 2.46 & 14.00 & 0.92 & 80.68 \\
\hline Polwe & Serranochromis angusticeps & scaled and filleted & $0.07 \pm 0.005$ & 1.58 & 23.27 & 0.89 & 80.86 \\
\hline Tigerfish & Hydrocynus vittatus & scaled and filleted & $0.04 \pm 0.007$ & 2.81 & 12.92 & 1.45 & 75.38 \\
\hline Tilapia & Orecochromis niloticus & scaled and filleted & $0.17 \pm 0.027$ & 4.01 & 13.02 & 1.31 & 73.91 \\
\hline Tilapia & Orecochromis niloticus & scaled and filleted & $0.15 \pm 0.009$ & 2.43 & 10.85 & 1.76 & 80.9 \\
\hline Tilapia & Orecochromis niloticus & scaled and filleted & $0.17 \pm 0.005$ & 3.28 & 14.84 & 1.86 & 72.17 \\
\hline Tilapia & Oreochromis tanganicae & scaled and filleted & $0.10 \pm 0.009$ & 3.56 & 6.38 & 1.79 & 78.98 \\
\hline Tilapia & Tilapia & scaled and filleted & $0.09 \pm 0.003$ & 2.28 & 9.55 & 1.94 & 80.61 \\
\hline \multicolumn{8}{|l|}{ Medium fish fresh } \\
\hline Choko Choko & Synodontis sambuesis & washed and filleted & $0.10 \pm 0.004$ & 2.66 & 13.49 & 3.66 & 67.94 \\
\hline Matuku & Tilpia sparrmanii & scaled and filleted & $0.13 \pm 0.035$ & 2.29 & 9.17 & 1.46 & 80.57 \\
\hline Mbilia & Sagrochromis codringtonii & scaled and filleted & $0.21 \pm 0.053$ & - & - & - & 77.68 \\
\hline Mbilya & Sargochromis mellandi & washed and left whole & $0.20 \pm 0.081$ & 2.18 & 27.07 & 4.50 & 73.86 \\
\hline Mintesa & Marcusenius macrolepidatus & gutted and scaled & $0.36 \pm 0.019$ & 1.29 & 7.38 & 4.81 & 71.93 \\
\hline Mpende & Coptodon (Tilapia) rendalli & scaled and filleted & $0.18 \pm 0.024$ & 3.59 & 11.73 & 0.99 & 78.56 \\
\hline Mpende & Coptodon (Tilapia) rendalli & scaled and filleted & $0.13 \pm 0.029$ & 2.56 & 8.39 & 1.40 & 80.94 \\
\hline Nkamba & Oreochromis machrochir & scaled and filleted & $0.12 \pm 0.006$ & 3.98 & 6.02 & 2.28 & 79.28 \\
\hline \multicolumn{8}{|l|}{ Small fish fresh } \\
\hline Inchunga & Barbus radiatus & washed and left whole & $0.06 \pm 0.012$ & - & - & - & 77.01 \\
\hline Inchunga & Barbus radiatus & washed and left whole & $0.06 \pm 0.006$ & 1.11 & 8.83 & 7.75 & 73.71 \\
\hline Inchunga & Barbus radiatus & washed and left whole & $0.11 \pm 0.010$ & 1.82 & 21.74 & 14.91 & 65.34 \\
\hline Kapela & - & washed and left whole & $0.09 \pm 0.003$ & 2.89 & 16.61 & 12.66 & 70.69 \\
\hline Kapenta & $\begin{array}{l}\text { Limnothrissa miodon \& } \\
\text { Stolothrissa tanganicae }\end{array}$ & washed and left whole & $0.09 \pm 0.023$ & 3.62 & 14.14 & 9.69 & 77.63 \\
\hline Kapenta & $\begin{array}{l}\text { Limnothrissa miodon \& } \\
\text { Stolothrissa tanganicae }\end{array}$ & washed and gutted & $0.08 \pm 0.001$ & 2.97 & 16.12 & 7.82 & 76.68 \\
\hline Matuku & Tilipia sparrmanii & washed and left whole & $0.15 \pm 0.025$ & - & - & - & 77.01 \\
\hline \multicolumn{8}{|l|}{ Big fish smoked } \\
\hline Inyenda & Clarias gariepinus & heads and bones removed & $0.12 \pm 0.029$ & 4.26 & 21.55 & 5.28 & 66.8 \\
\hline Mbubu & Mormyrus lacerde & heads and bones removed & $0.32 \pm 0.10$ & 4.03 & 44.00 & 3.80 & 9.84 \\
\hline Mbubu & Mormyrus Lacerde & heads and bones removed & $0.38 \pm 0.08$ & 5.02 & 70.10 & 3.31 & 7.61 \\
\hline Tilapia & Orecochromis niloticus & heads and bones removed & $0.38 \pm 0.10$ & 8.67 & 12.80 & 3.44 & 17.39 \\
\hline \multicolumn{8}{|l|}{ Medium fish smoked } \\
\hline Choko Choko & Synodontis sambuesis & heads and bones removed & $0.10 \pm 0.001$ & 7.65 & 19.00 & 8.40 & 8.23 \\
\hline Distichodus maculatus & Distichodus maculatus & left whole & $0.13 \pm 0.04$ & 4.57 & 83.60 & 52.20 & 8.17 \\
\hline Inyenda. Bomba and Mulonge & $\begin{array}{l}\text { Mix of Clarias gariepinus. } \\
\text { Stappersii.theodorae }\end{array}$ & heads and bones removed & $0.21 \pm 0.01$ & 8.35 & 48.90 & 33.80 & 9.09 \\
\hline
\end{tabular}


Table 5 (continued)

\begin{tabular}{|c|c|c|c|c|c|c|c|}
\hline \multirow[t]{2}{*}{ Species name (local) } & \multirow[t]{2}{*}{ Species name (scientific) } & \multirow[t]{2}{*}{ Kind of preparation } & \multicolumn{5}{|c|}{ Content per $100 \mathrm{~g}$ edible portion } \\
\hline & & & $\begin{array}{l}\text { Riboflavin } \\
{[\mathrm{mg}]}\end{array}$ & $\begin{array}{l}\text { Niacin } \\
{[\mathrm{mg}]}\end{array}$ & $\begin{array}{l}\text { Folate } \\
{[\mu \mathrm{g}]}\end{array}$ & 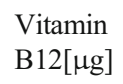 & $\begin{array}{l}\text { Water } \\
{[\mathrm{g}]}\end{array}$ \\
\hline Mbilya & Sagrochromis mellandi & heads and bones removed & $0.80 \pm 0.04$ & 9.33 & 46.70 & 12.10 & 12.04 \\
\hline Mintesa & Marcusenius macrolepidatus & gutted and scaled & $0.94 \pm 0.06$ & 4.17 & 30.60 & 22.40 & 5.79 \\
\hline Mpende & Coptodon (Tilapia) rendalli & heads and bones removed & $0.73 \pm 0.24$ & 12.50 & 33.70 & 4.28 & 19.7 \\
\hline Nsuku & Serranchromis robustus & heads and bones removed & $0.29 \pm 0.06$ & 6.87 & 27.60 & 8.57 & 9.95 \\
\hline Nsuku & Serranchromis robustus & heads and bones removed & $0.33 \pm 0.07$ & 7.99 & 39.40 & 7.37 & 21.17 \\
\hline Nsuku & Serranchromis robustus & heads and bones removed & $0.41 \pm 0.03$ & 9.80 & 50.60 & 6.93 & 13.46 \\
\hline Polwe & Serranochromis angusticeps & heads and bones removed & $0.30 \pm 0.06$ & 5.39 & 40.60 & 3.70 & 22.37 \\
\hline Silver Catfish & Schilbe intermedius & heads and bones removed & $0.19 \pm 0.01$ & 4.22 & 33.30 & 15.80 & 13.72 \\
\hline \multicolumn{8}{|l|}{ Small fish smoked } \\
\hline Matuku & Tilapia sparrmanii & heads and bones removed & $0.79 \pm 0.04$ & 8.12 & 31.10 & 9.19 & 8.37 \\
\hline \multicolumn{8}{|l|}{ Small fish sun-dried } \\
\hline Chisense & Poecilothrissa mweruensis & left whole & $0.16 \pm 0.02$ & 7.30 & 53.50 & 25.00 & 7.34 \\
\hline Icele and Icimpumwe & $\begin{array}{l}\text { Mixture of Petrocephalus\& } \\
\text { Cyphomyrus }\end{array}$ & left whole & $0.68 \pm 0.08$ & 3.72 & 71.10 & 22.10 & 7.45 \\
\hline Imfindu & Pseudocrenilabrus philander & left whole & $1.22 \pm 0.13$ & 6.51 & 51.00 & 37.10 & 8.69 \\
\hline Inchunga & Barbus radiatus & left whole & $0.11 \pm 0.02$ & 4.05 & 80.50 & 26.00 & 9.56 \\
\hline Ishimba & Pollimyrus cf. isidori/castelnaui & left whole & $1.00 \pm 0.03$ & 7.05 & 67.10 & 60.10 & 9.5 \\
\hline Kapenta & $\begin{array}{l}\text { Limnothrissa miodon \& } \\
\text { Stolothrissa tanganicae }\end{array}$ & left whole & $0.15 \pm 0.01$ & 17.30 & 43.80 & 33.30 & 9.00 \\
\hline Kapenta & $\begin{array}{l}\text { Limnothrissa miodon \& } \\
\text { Stolothrissa tanganicae }\end{array}$ & left whole & $0.40 \pm 0.02$ & 20.70 & 63.00 & 41.10 & 11.21 \\
\hline Kapenta & $\begin{array}{l}\text { Limnothrissa miodon \& } \\
\text { Stolothrissa tanganicae }\end{array}$ & left whole & $0.21 \pm 0.02$ & 20.20 & 64.10 & 36.60 & 9.33 \\
\hline Matuku & Tilapia sparrmanii & left whole & $1.29 \pm 0.43$ & - & - & - & 9.01 \\
\hline Matuku & Tilapia sparrmanii & left whole & $1.04 \pm 0.10$ & 6.61 & 42.20 & 29.60 & 7.71 \\
\hline Microlestis sardinae & Microlestis sardinae & left whole & $0.20 \pm 0.01$ & 5.52 & 30.60 & 29.50 & 7.8 \\
\hline Mintesa & Marcusenius macrolepidatus & gutted and scaled & $0.71 \pm 0.05$ & 4.94 & 84.10 & 52.80 & 10.54 \\
\hline Misenga & Barbus paludinosus & left whole & $0.23 \pm 0.01$ & 6.25 & 54.10 & 44.40 & 8.96 \\
\hline Mushipa & Barbus trimaculatus & left whole & $0.14 \pm 0.004$ & 4.91 & 52.40 & 30.60 & 8.89 \\
\hline Popa & $\begin{array}{l}\text { Mixture of Haplochromin } \\
\text { Cychlid and a kind of "sardine" }\end{array}$ & left whole & $1.13 \pm 0.06$ & 11.50 & 47.00 & 64.20 & 10.38 \\
\hline Silver Catfish & Schilbe intermedius & heads and bones removed & $0.19 \pm 0.02$ & 6.37 & 125.00 & 24.00 & 9.12 \\
\hline Swamp Barb mix & Mixture of small barbus & left whole & $0.23 \pm 0.01$ & 5.29 & 42.50 & 41.50 & 8.75 \\
\hline
\end{tabular}

For Riboflavin $n=3$. for other vitamins $n=1$

Kind of preparation is equal to analysed parts

Fresh fish are presented on a fresh weight basis. Processed fish are presented with their residual water content

(Popa), with a mean value of $2126.01 \pm 1435.66 \mathrm{mg} / 100 \mathrm{~g}$ EP. Iron contents ranged from $1.29 \mathrm{mg} / 100 \mathrm{~g}$ EP (Nsuku) to $70.08 \mathrm{mg} / 100 \mathrm{~g}$ (Matuku), with a mean value of $13.13 \pm$ $13.55 \mathrm{mg} / 100 \mathrm{~g}$ EP. Zinc contents ranged from $1.53 \mathrm{mg} /$ $100 \mathrm{~g}$ EP (Inyenda) to $22.02 \mathrm{mg} / 100 \mathrm{~g}$ EP (Microlestis sardinae), with a mean value of $8.74 \pm 5.45 \mathrm{mg} / 100 \mathrm{~g}$ EP. Processed small fish also contained higher mean amounts of all three minerals, however with smaller differences. Mean calcium content of small fish was 6 times higher than the mean calcium content of large fish and about 3 times higher than mean calcium content of medium fish. Mean contents of iron and zinc found in small fish were about 3 to 4 times higher, compared to large and medium fish. Interestingly the sample of smoked Inyenda, which usually showed the lowest nutrient levels of all processed fish due to its high water content (see 3.1.), had the highest iron content of all processed large and medium fish species $(13.65 \mathrm{mg} / 100 \mathrm{~g}$ edible portion) and rivalled even the iron content of many samples of small fish. 
Table 6 Mineral composition of fresh and processed fish samples

\begin{tabular}{|c|c|c|c|c|c|c|c|c|c|}
\hline \multirow[t]{2}{*}{ Species name (local) } & \multirow[t]{2}{*}{ Species name (scientific) } & \multirow[t]{2}{*}{ Kind of preparation } & \multicolumn{7}{|c|}{ Content per $100 \mathrm{~g}$ edible portion } \\
\hline & & & $\begin{array}{l}\mathrm{Ca} \\
{[\mathrm{mg}]}\end{array}$ & $\begin{array}{l}\mathrm{Fe} \\
{[\mathrm{mg}]}\end{array}$ & $\begin{array}{l}\mathrm{Zn} \\
{[\mathrm{mg}]}\end{array}$ & $\begin{array}{l}\mathrm{K} \\
{[\mathrm{mg}]}\end{array}$ & $\begin{array}{l}\mathrm{Mg} \\
{[\mathrm{mg}]}\end{array}$ & $\begin{array}{l}\mathrm{Se} \\
{[\mu \mathrm{g}]}\end{array}$ & $\begin{array}{l}\text { Water } \\
{[\mathrm{g}]}\end{array}$ \\
\hline \multicolumn{10}{|l|}{ Big fish fresh } \\
\hline Buka buka & Luciolates & scaled and filleted & 30.13 & 0.82 & 0.57 & 326.42 & 28.08 & 128.23 & 73.67 \\
\hline Horse mackerel & Trachurus capensis & scaled and filleted & 62.47 & 1.26 & 1.08 & 333.12 & 46.98 & 85.56 & 77.69 \\
\hline Inyenda & Clarias gariepinus & washed and filleted & 10.15 & 0.73 & 0.66 & 296.30 & 21.53 & 36.38 & 81.40 \\
\hline Kalongwe & Labeo cylindricus & scaled and filleted & 41.54 & 0.45 & 0.93 & 230.61 & 23.46 & 61.40 & 82.58 \\
\hline Mbowa & Auchenoglanis occidentalis & washed and filleted & 13.67 & 0.36 & 0.44 & 280.75 & 20.29 & 15.24 & 81.51 \\
\hline Mbubu & Mormyrops deliciosus & scaled and filleted & 26.04 & 0.30 & 0.95 & 195.69 & 18.42 & 23.59 & 79.95 \\
\hline Mbubu & Mormyrus longirostris & scaled and filleted & 37.22 & 0.45 & 0.37 & 159.51 & 16.65 & 25.35 & 83.38 \\
\hline Mpende & Coptodon (Tilapia) rendalli & scaled and filleted & 23.29 & 0.20 & 0.86 & 262.93 & 21.34 & 21.74 & 79.35 \\
\hline Nsuku & Serranchromis robustus & scaled and filleted & 31.57 & 0.22 & 0.55 & 271.90 & 21.25 & 20.36 & 82.79 \\
\hline Nsuku & Serranchromis robustus & scaled and filleted & 30.86 & 0.29 & 0.78 & 219.13 & 20.45 & 21.54 & 80.68 \\
\hline Polwe & Serranochromis angusticeps & scaled and filleted & 19.93 & 0.21 & 0.63 & 314.14 & 24.19 & 23.89 & 80.86 \\
\hline Tigerfish & Hydrocynus vittatus & scaled and filleted & 23.18 & 0.31 & 0.86 & 299.45 & 24.37 & 28.25 & 75.38 \\
\hline Tilapia & Orecochromis niloticus & scaled and filleted & 26.55 & 0.40 & 0.72 & 323.71 & 26.05 & 14.48 & 73.91 \\
\hline Tilapia & Orecochromis niloticus & scaled and filleted & 45.15 & 0.33 & 0.68 & 305.32 & 22.18 & 19.43 & 80.90 \\
\hline Tilapia & Orecochromis niloticus & scaled and filleted & 48.61 & 0.58 & 0.89 & 353.58 & 28.89 & 19.12 & 72.17 \\
\hline Tilapia & Oreochromis tanganicae & scaled and filleted & 16.01 & 0.26 & 1.11 & 344.39 & 25.27 & 28.57 & 78.98 \\
\hline Tilapia & Tilapia & scaled and filleted & 54.71 & 0.71 & 0.91 & 231.89 & 23.03 & 54.61 & 80.61 \\
\hline \multicolumn{10}{|l|}{ Medium fish fresh } \\
\hline Choko Choko & Synodontis sambuesis & washed and filleted & 26.80 & 0.55 & 0.53 & 189.92 & 16.21 & 76.90 & 67.94 \\
\hline Matuku & Tilpia sparrmanii & scaled and filleted & 54.88 & 0.38 & 1.02 & 226.13 & 21.50 & 132.19 & 80.57 \\
\hline Mbilia & Sagrochromis codringtonii & scaled and filleted & 55.64 & 0.52 & 1.05 & 240.67 & 23.00 & 50.39 & 77.68 \\
\hline Mbilya & Sargochromis mellandi & washed and left whole & 1028.35 & 2.98 & 2.16 & 260.49 & 42.80 & 38.75 & 73.86 \\
\hline Mintesa & Marcusenius macrolepidatus & gutted and scaled & 692.24 & 1.19 & 3.41 & 290.96 & 35.72 & 33.95 & 71.93 \\
\hline Mpende & Coptodon (Tilapia) rendalli & scaled and filleted & 58.55 & 0.41 & 1.14 & 333.52 & 26.60 & 23.57 & 78.56 \\
\hline Mpende & Coptodon (Tilapia) rendalli & scaled and filleted & 48.98 & 0.44 & 1.16 & 206.41 & 19.91 & 50.22 & 80.94 \\
\hline Nkamba & Oreochromis machrochir & scaled and filleted & 41.90 & 0.40 & 1.22 & 335.06 & 23.62 & 19.49 & 79.28 \\
\hline \multicolumn{10}{|l|}{ Small fish fresh } \\
\hline Inchunga & Barbus radiatus & washed and left whole & 915.36 & 0.94 & 3.46 & 211.06 & 35.60 & 29.52 & 77.01 \\
\hline Inchunga & Barbus radiatus & washed and left whole & 1044.88 & 4.11 & 4.62 & 243.36 & 42.81 & 43.21 & 73.71 \\
\hline Inchunga & Barbus radiatus & washed and left whole & 1324.38 & 6.74 & 5.18 & 284.48 & 56.12 & 43.89 & 65.34 \\
\hline Kapela & - & washed and left whole & 1151.20 & 7.28 & 13.73 & 302.02 & 53.47 & 61.19 & 70.69 \\
\hline Kapenta & Limnothrissa miodon & washed and left whole & 823.80 & 2.86 & 3.71 & 340.42 & 41.64 & 35.41 & 77.63 \\
\hline Kapenta & Limnothrissa miodon & washed and gutted & 893.10 & 3.60 & 3.19 & 242.15 & 41.54 & 60.81 & 76.68 \\
\hline Matuku & Tilipia sparrmanii & washed and left whole & 1055.05 & 16.06 & 2.35 & 232.51 & 37.93 & 24.40 & 77.01 \\
\hline \multicolumn{10}{|l|}{ Big fish smoked } \\
\hline Inyenda & Clarias gariepinus & $\begin{array}{l}\text { heads and bones } \\
\text { removed }\end{array}$ & 15.08 & 13.65 & 1.53 & 500.01 & 29.46 & 43.04 & 66.80 \\
\hline Mbubu & Mormyrus lacerde & $\begin{array}{l}\text { heads and bones } \\
\text { removed }\end{array}$ & 1169.34 & 3.73 & 5.02 & 806.14 & 84.82 & 107.62 & 9.84 \\
\hline Mbubu & Mormyrus Lacerde & $\begin{array}{l}\text { heads and bones } \\
\text { removed }\end{array}$ & 840.90 & 2.97 & 8.36 & 1047.01 & 105.29 & 108.16 & 7.61 \\
\hline Tilapia & Orecochromis niloticus & $\begin{array}{l}\text { heads and bones } \\
\text { removed }\end{array}$ & 242.34 & 3.84 & 1.78 & 1076.40 & 88.42 & 100.69 & 17.39 \\
\hline \multicolumn{10}{|l|}{ Medium fish smoked } \\
\hline Choko Choko & Synodontis sambuesis & $\begin{array}{l}\text { heads and bones } \\
\text { removed }\end{array}$ & 304.80 & 7.18 & 2.78 & 806.30 & 70.64 & 111.05 & 8.23 \\
\hline Distichodus maculatus & Distichodus maculatus & left whole & 2981.06 & 11.94 & 6.78 & 1007.79 & 143.91 & 43.10 & 8.17 \\
\hline $\begin{array}{l}\text { Inyenda. Bomba and } \\
\text { Mulonge }\end{array}$ & $\begin{array}{l}\text { Mix of Clarias gariepinus. } \\
\text { Stappersii.theodorae }\end{array}$ & $\begin{array}{l}\text { heads and bones } \\
\text { removed }\end{array}$ & 482.83 & 8.97 & 3.05 & 1243.53 & 104.73 & 222.35 & 9.09 \\
\hline Mbilya & Sagrochromis mellandi & $\begin{array}{l}\text { heads and bones } \\
\text { removed }\end{array}$ & 899.09 & 2.95 & 4.62 & 1081.65 & 102.00 & 116.30 & 12.04 \\
\hline Mintesa & Marcusenius macrolepidatus & gutted and scaled & 2518.83 & 8.68 & 11.86 & 981.06 & 131.01 & 121.95 & 5.79 \\
\hline Mpende & Coptodon (Tilapia) rendalli & $\begin{array}{l}\text { heads and bones } \\
\text { removed }\end{array}$ & 323.06 & 1.82 & 4.88 & 1116.77 & 84.35 & 105.64 & 19.70 \\
\hline Nsuku & Serranchromis robustus & $\begin{array}{l}\text { heads and bones } \\
\text { removed }\end{array}$ & 715.82 & 3.33 & 3.65 & 1400.07 & 111.06 & 130.68 & 9.95 \\
\hline Nsuku & Serranchromis robustus & $\begin{array}{l}\text { heads and bones } \\
\text { removed }\end{array}$ & 471.34 & 1.29 & 3.75 & 1211.30 & 94.92 & 113.52 & 21.17 \\
\hline Nsuku & Serranchromis robustus & $\begin{array}{l}\text { heads and bones } \\
\text { removed }\end{array}$ & 967.74 & 2.78 & 4.00 & 1248.08 & 98.56 & 99.56 & 13.46 \\
\hline
\end{tabular}


Table 6 (continued)

\begin{tabular}{|c|c|c|c|c|c|c|c|c|c|}
\hline \multirow[t]{2}{*}{ Species name (local) } & \multirow[t]{2}{*}{ Species name (scientific) } & \multirow[t]{2}{*}{ Kind of preparation } & \multicolumn{7}{|c|}{ Content per $100 \mathrm{~g}$ edible portion } \\
\hline & & & $\begin{array}{l}\mathrm{Ca} \\
{[\mathrm{mg}]}\end{array}$ & $\begin{array}{l}\mathrm{Fe} \\
{[\mathrm{mg}]}\end{array}$ & $\begin{array}{l}\mathrm{Zn} \\
{[\mathrm{mg}]}\end{array}$ & $\begin{array}{l}\mathrm{K} \\
{[\mathrm{mg}]}\end{array}$ & $\begin{array}{l}\mathrm{Mg} \\
{[\mathrm{mg}]}\end{array}$ & $\begin{array}{l}\mathrm{Se} \\
{[\mu \mathrm{g}]}\end{array}$ & $\begin{array}{l}\text { Water } \\
{[\mathrm{g}]}\end{array}$ \\
\hline Polwe & Serranochromis angusticeps & $\begin{array}{l}\text { heads and bones } \\
\text { removed }\end{array}$ & 527.52 & 1.58 & 3.15 & 1128.16 & 96.06 & 99.76 & 22.37 \\
\hline Silver Catfish & Schilbe intermedius & $\begin{array}{l}\text { heads and bones } \\
\text { removed }\end{array}$ & 978.12 & 7.67 & 4.06 & 1084.39 & 116.56 & 103.41 & 13.72 \\
\hline \multicolumn{10}{|l|}{ Small fish smoked } \\
\hline Matuku & Tilapia sparrmanii & $\begin{array}{l}\text { heads and bones } \\
\text { removed }\end{array}$ & 1899.73 & 5.78 & 6.72 & 1173.86 & 130.79 & 102.23 & 8.37 \\
\hline \multicolumn{10}{|l|}{ Small fish sun-dried } \\
\hline Chisense & Poecilothrissa mweruensis & left whole & 2975.32 & 22.14 & 19.29 & 1325.51 & 171.18 & 106.51 & 7.34 \\
\hline Icele and Icimpumwe & $\begin{array}{l}\text { Mixture of } \\
\quad \text { Petrocephalus\&Cyphomyrus }\end{array}$ & left whole & 2253.13 & 10.63 & 10.43 & 712.74 & 97.35 & 93.12 & 7.45 \\
\hline Imfindu & Pseudocrenilabrus philander & left whole & 4361.03 & 17.31 & 10.90 & 1134.76 & 168.69 & 65.73 & 8.69 \\
\hline Inchunga & Barbus radiatus & left whole & 4186.52 & 9.58 & 13.83 & 894.93 & 167.03 & 168.97 & 9.56 \\
\hline Ishimba & Pollimyrus cf. isidori/castelnaui & left whole & 2748.48 & 15.43 & 9.04 & 1188.06 & 146.14 & 69.57 & 9.50 \\
\hline Kapenta & Limnothrissa miodon & left whole & 2713.82 & 9.06 & 13.37 & 1421.30 & 162.74 & 158.51 & 9.00 \\
\hline Kapenta & Limnothrissa miodon & left whole & 1869.47 & 14.09 & 7.84 & 1340.43 & 148.37 & 260.05 & 11.21 \\
\hline Kapenta & Limnothrissa miodon & left whole & 1390.74 & 31.67 & 6.55 & 1575.57 & 165.70 & 273.54 & 9.33 \\
\hline Matuku & Tilapia sparrmanii & left whole & 4225.79 & 70.08 & 10.79 & 991.48 & 150.58 & 139.16 & 9.01 \\
\hline Matuku & Tilapia sparrmanii & left whole & 3463.83 & 38.01 & 9.42 & 1083.65 & 136.90 & 44.52 & 7.71 \\
\hline Microlestis sardinae & Microlestis sardinae & left whole & 4109.67 & 12.65 & 22.02 & 962.83 & 160.09 & 116.91 & 7.80 \\
\hline Mintesa & Marcusenius macrolepidatus & gutted and scaled & 2882.47 & 20.01 & 13.76 & 1156.45 & 151.83 & 149.37 & 10.54 \\
\hline Misenga & Barbus paludinosus & left whole & 3477.89 & 13.21 & 9.93 & 928.33 & 146.57 & 48.83 & 8.96 \\
\hline Mushipa & Barbus trimaculatus & left whole & 3001.25 & 11.30 & 12.05 & 920.73 & 130.95 & 100.71 & 8.89 \\
\hline Popa & $\begin{array}{l}\text { Mixture of Haplochromin } \\
\text { Cychlid and a kind of "sardine" }\end{array}$ & left whole & 4478.31 & 10.35 & 16.10 & 1233.82 & 165.90 & 158.64 & 10.38 \\
\hline Silver Catfish & Schilbe intermedius & $\begin{array}{l}\text { heads and bones } \\
\text { removed }\end{array}$ & 2781.15 & 9.08 & 6.56 & 1157.22 & 142.88 & 143.77 & 9.12 \\
\hline Swamp Barb mix & Mixture of small barbus & left whole & 3901.99 & 30.66 & 20.66 & 1177.17 & 174.70 & 154.61 & 8.75 \\
\hline
\end{tabular}

$\mathrm{n}=2$

Kind of preparation is equal to analysed parts

Fresh fish are presented on a fresh weight basis. Processed fish are presented with their residual water content

\section{Discussion}

\subsection{Proximate composition and fatty acids}

The findings of this study on the protein content of processed fish (27.79-82.40 g/100 g EP) suggest a wider range of protein content in processed fish, compared to the range of protein content found in fresh fish (13.13-23.20 g/100 g EP). However this is mainly due to the high residual water content found in the sample of smoked Inyenda, which was closer to the water contents found in fresh fish. Compared to unprocessed fish of the same size group, it actually showed a very high amount of protein, containing almost twice as much protein as the unprocessed sample of Inyenda. The protein content of the other processed fish is more uniform, as indicated by the mean protein content $(64.26 \pm 7.52 \mathrm{~g} / 100 \mathrm{~g} \mathrm{EP})$. Our findings on the protein content of fresh and processed fish are largely supported by literature sources (Lukmanji et al. 2008; Bogard et al. 2015). Our results on fat content are similar to results to data from Steiner-Asiedu et al. (1993) and Nyirenda
(2009) for both fresh and processed fish. Results from the present work on the water content of fish are also in accordance with other literature sources (Bogard et al. 2015; Lukmanji et al. 2008).

With regard to fatty acids, our findings of lower percentages of linoleic acid in processed fish than in fresh fish of the same species may be explained by the degradation of fatty acids during the long processing time. Similarly, the generally higher percentage of fatty acids found in smoked samples is probably caused by the longer processing time of sun-dried samples (as indicated by fishermen), leading to the degradation of fatty acids. Aside from the study of Steiner-Asiedu et al. (1993) there is nearly no data on fatty acid composition of fish from Zambia. Their data on fatty acid composition of dried Kapenta and dried Chisense is comparable with results from this study, despite a slightly lower percentage of DHA and EPA in the latter. The results of this study are well within the range of reported fatty acid percentages, when compared to fresh water species from Europe (Linhartová et al. 2018). Interestingly, while some of the highest percentages of DHA 
and EPA were found in Horse mackerel, other fish (often small fish species) showed similar or higher percentages of both fatty acids. This is counter intuitive since Horse mackerel is a marine fish, which usually contain higher levels of both EPA and DHA, than the samples analysed in this study. Both of these fatty acids are crucial for proper cognitive development; therefore nutrition projects in a Zambian setting should ensure their consumption by focusing on more accessible small fish species such as Kapenta, instead of trying to promote less accessible marine fish (Swanson et al. 2012; Genschick et al. 2018).

\subsection{Vitamin composition}

Small fish generally contain higher levels of both folate and vitamin B12 compared to large and medium fish. This may result from the fact that small fish were usually analysed whole, including their innards. It has been reported that fish liver contains higher amounts of B-vitamins, including riboflavin, folate and vitamin B12, than regular fish muscle (Brækkan 1956). Other animal foods e.g. beef and chicken also show that innards in general contain higher amounts of B-Vitamins (Erhardt 2014). Furthermore the microbiota of fish can produce B-vitamins and the production vitamin B12 is especially well documented (Nayak 2010). Some species samples however contained high levels of folate (Polwe) and/ or vitamin B12 (Mintesa) although their innards had been removed prior to analysis. That was also the case in our overall findings on riboflavin content. This may result from differences in fish species, since the highest levels of riboflavin were found in fish belonging to the same or related species (Matuku, Mintesa etc.). Fish that showed unusually high folate contents for their processing type were also found to belong to the same species (Polwe). Still unidentified vitamin B12 stores in other fish organs could be a possible explanation for the high vitamin B12 contents found. Bogard et al. (2015) found that the adult version of one their samples, whose gills had been removed prior to analysis, contained less vitamin B12, than its juvenile counterpart with gills. Our finding that niacin contents are usually highest in large and larger medium fish is as expected because regular fish muscle contains higher levels of niacin compared to other parts of the fish (Brækkan 1956). However, high niacin contents in the small fish Kapenta and low niacin contents in several large fish species (Mbubu) also indicate some dependency on species. This is corroborated by Stadlmayr et al. (2012), who report low niacin contents in Mormyrids (the family to which all samples of Mbubu belong and high niacin contents in Anchovies. which are related to the species which compose Kapenta (Whitehead 1985).

Overall the mean riboflavin contents of fresh and processed fish found in this study are similar to earlier reports made for fish from South-Eastern (Lukmanji et al. 2008; Nyirenda 2009) and Western Africa (Stadlmayr et al. 2012). This study's findings on the mean niacin content of fresh fish are also well within the range reported by Lukmanji et al. (2008), but the reported levels of niacin in processed fish are much lower. Nyirenda (2009) also reports lower levels for processed fish, but also much lower niacin levels for fresh fish. Our findings on the folate content of fresh and processed fish are well within the range reported by literature studies (Lukmanji et al. 2008; Stadlmayr et al. 2012). While Bogard et al. (2015) found much lower levels of folate in fresh fish they confirm that small fish, which are consumed whole, usually contain higher levels of folate. This study's findings on vitamin B12 contents of large and small fish species are supported by Haug et al. (2010) and Bogard et al. (2015). Lukmanji et al. (2008) however, reported much lower vitamin B12 contents for fresh fish, regardless of the fish's size with only their dried samples containing similar amounts, to the findings presented here. The reasons for all reported differences might be due to factors such as species, processing technique, and the analytical methods used.

\subsection{Mineral composition}

This study found that small fish contained higher amounts of minerals than large and most medium fish, regardless of processing. This is caused by small fish still containing components rich in minerals such as bones, heads and innards (Julshamn et al. 1978; Kawarazuka and Béné 2011). Large fish on the other hand, had all these removed prior to analysis. This is especially pronounced in species like Matuku, where samples can be found in different size groups. It was also found that differences in mineral content between small and medium fish aren't as pronounced as between small and large fish. This is mainly due to the samples of Distichodus maculatus, Mbilya and Mintesa, which are consumed whole or only have their innards removed and thus contain more minerals than other samples from this size group. Although analysing some samples with bones and some without could be seen as an error, our aim was to create representative nutrient profiles of fish and fish products eaten in Zambia and thus to mimic as closely as possible Zambian eating habits.. The finding that differences in mineral content between the three size groups were less pronounced in processed fish can be explained by two factors. First the bones of large and medium fish were very brittle and couldn't be removed completely while preparing the samples for analysis. Secondly large and medium samples were analysed with their skin, which can contain substantial amounts of minerals (Kabahenda et al. 2011). The generally low water contents of processed samples could thus lead to a concentration of minerals in the skin.

Data, on calcium levels of small and large fresh fish from Bangladesh and West Africa show that our findings are well within the range of calcium contents commonly found in fresh fish, although there is some indication in their data that other 
factors than just size and preparation influence a fish's calcium content (Stadlmayr et al. 2012; Bogard et al. 2015). Steiner-Asiedu et al. (1993) report calcium, iron and zinc levels in samples of dried Kapenta and Chisense which are very similar to this study's findings when compared on a dry weight basis (data not shown). While Nyirenda (2009) reports calcium levels for fresh and dried Kapenta, which are also comparable to our findings, her findings on the calcium content of fresh Barbus species are considerably lower. This could be due to analysing one of the bigger species of the Barbus family, where probably only the flesh was used for analysis, whereas the species analysed in this study (Inchunga or Barbus radiatus) is very small and consumed whole. Data on iron and zinc contents of fresh fish from Bogard et al. (2015) shows similar contents in large and small fish species, although the zinc contents found in of our study can be a bit higher, probably due to differences in location, species or the analytical methods used.

\section{Contribution of fish to the RDI of selected micronutrients}

In addition to analysing the nutrient composition of the collected samples, the contribution of fish towards achieving the Recommended Daily Intakes (RDI) of the presented micronutrients was also investigated. As the mean daily intake of fish is quite small, the grams of fish needed to satisfy the RDIs was also calculated. The following section focuses on women, and children older than 4 years due to their higher RDIs, which are harder to meet than the RDIs of 1-3 year olds. The RDI percentages presented below are per $100 \mathrm{~g}$ EP. Detailed results for both variables of all analysed samples can be seen in the Appendix 3 (page 2-page 5).

It was found that fresh and dried Kapenta, which have been identified as the most consumed fish products of poor consumers in Lusaka (Genschick et al. 2018) are both excellent sources of vitamin B12 providing (326-404\% \& 1388$1713 \%$ of the RDI) and amounts of about $30 \mathrm{~g}$ fresh and 6$7 \mathrm{~g}$ processed are enough to provide the RDI of vitamin B12. However other small fresh fish such as Inchunga (323-621\% of the RDI) and other small dried fish (most notably Popa, which can provide about $2675 \%$ of the RDI), would provide enough vitamin B12 in equal or even smaller portions to fulfil its RDI and are equally accessible at their respective sampling sites. While large fish such as Buka buka (234\% of the RDI), Horse mackerel (387\% of the RDI) and samples of Tilapia (55-77\% of the RDI), could also contribute substantially to the RDI of vitamin B12 they are only more accessible to poor consumers of higher socio-economic standing (Genschick et al. 2018). It is therefore not surprising that fish is found to be the most important source of vitamin B12 in the Zambian diet (Halimatou et al. 2014).
Small fish and especially dried small fish were the best sources of calcium providing 63-102\% (fresh) and 107$344 \%$ (processed) of the RDI. The mean amount of small fresh fish necessary to achieve the RDI of calcium is a bit too high $(129.2 \pm 20.6 \mathrm{~g})$ to rely on fish alone, but is at least fairly close to the mean daily intake reported for women, while the mean amount of small dried fish $(44.4 \pm 16.7 \mathrm{~g})$ would provide enough calcium to reach the RDI. These are encouraging findings as calcium deficiencies are widely found in Zambia (Halimatou et al. 2014; Marinda et al. 2018). Medium fish such as Mintesa can be excellent sources of calcium too, as they are consumed with their bones, providing between 53\% (fresh), 194\% (smoked) and 222\% (sun-dried) of the RDI. Small processed fish are also the best sources of iron and zinc (50-389\% of the RDI of iron and $60-200 \%$ of the RDI of zinc). The amounts necessary to be eaten to reach the RDI, is often far higher than $100 \mathrm{~g}$ for both minerals. This can be somewhat excessive, given that fish is likely to be the only food source to sufficiently provide both minerals (Nyirenda et al. 2007; Halimatou et al. 2014). One exception is Kapenta where 25-50 g are sufficient to reach the RDI of iron. While large and medium processed fish (without bones, head and innards) can be excellent sources of all three minerals and are much better sources, than their fresh counterparts, their accessibility is unknown making it hard to know how helpful they could be in combating hidden hunger. The only exception would be processed Tilapia, which is relatively accessible to poorer consumers (Genschick et al. 2018).

In contrast to the micronutrients discussed so far, the best sources for niacin are usually large fish species especially Buka buka (48\% of the RDI) and Horse mackerel (33\% of the RDI). While somewhat accessible, they are often still too costly for poor consumers. It is therefore reassuring that sundried samples of the more accessible and widely available Kapenta (Longley et al. 2014; Genschick et al. 2018) show the highest niacin contents of all samples and can provide $108-129 \%$ of its RDI.

About $60 \%$ of all analysed samples can be considered to be good to excellent sources of riboflavin. However amounts between $400 \mathrm{~g}$ and up to $2 \mathrm{~kg}$ would be necessary, as most fish only fulfil between 10 and $30 \%$ of the RDI. This finding was mainly made for fresh, but also for processed fish regardless of size. Many processed fish were in fact only good sources of riboflavin due to their reduced water content. However there were some exceptions among processed samples (e.g. Mintesa Matuku, and Popa). Although none of these fish can provide the RDI in portions below $100 \mathrm{~g}$ (mean value $125.7 \pm 21.6$ ), these amounts are still far more achievable regarding the mean daily fish intake of women.

In accordance with Bogard et al. (2015) none of the analysed fish could contribute much to folate intake, although small fish were somewhat better folate sources than medium and large fish. The findings for women reported above mostly 
hold true for children aged 1-3 also.. However many fish became far better sources of iron, zinc and especially riboflavin and folate, due to the lower RDI values of this age group. Therefore fish have a high potential to contribute to the RDI of various micronutrients, but this is often hampered by the generally low intake of fish.

\section{Limitations}

The nutritional composition of fish can vary seasonally (Bogard et al. 2015). However we did not take this into account in the present study. According to fishermen and the Department of Fisheries, the time in which sample collection took place was unideal for small fresh fish. Small fish are also immediately dried after being caught, the only exception being Kapenta. As small dried fish species were often only sold as Kasepa mix it was often necessary to analyse these mixed samples, as separation into single species was impossible. Due to availability at the sampling sites it wasn't always possible to obtain enough sample material for conducting all the planned analyses. Therefore data on nutritional composition is missing for some samples and only single value analysis could be performed for niacin, folate and vitamin B12 (see Tables 3, 4, 5 and 6). Due to the aim and mode of conduct of the study, statistical analysis is mostly lacking. Future studies need to be conducted to analyse the effects of variables such as processing or water body on the nutrient composition. Despite all these limitations, this study was able to generate a large amount of information about the nutritional composition of many fish species from Zambia.

\section{Conclusion}

To our knowledge this is the first study with an extensive analysis on the nutrient composition of fish species consumed in Zambia. While some large fish species such as Buka buka and Horse mackerel are nutrient dense and a high quality protein source, their cost makes them inaccessible to poor consumers. Small fish species such as, Popa, Inchunga and especially Kapenta, on the other hand are highly accessible for poor consumers and have been shown to be a rich source for micronutrients especially vitamin B12, calcium, iron and zinc. They often show the highest percentage share of EPA and DHA too. Therefore it is not surprising that children who don't consume small fish are more likely to be stunted and suffer from hidden hunger than those who do (Biesalski 2013; Marinda et al. 2018). To combat this phenomenon early on, small sun-dried fish could be powdered and used to fortify maize based weaning foods for infants, which usually lack micronutrients (Owino et al. 2008; Haug et al. 2010). As a powder they can also supplement micronutrients which can be low on a fresh weight basis e.g. riboflavin and folate, as drying has been shown to concentrate the amounts of micronutrients. Given the importance of small fish for the nutritional status of poor consumers and especially for poor children, strategies must be found to increase its overall consumption and ensure an ongoing supply of fish, especially small fish. To achieve that, several actions have to take place beforehand. At first policy makers and NGOs related to nutritional programs must be educated about the nutritional benefits of small fish species compared to large fish species. Secondly consumption studies should be conducted in all of Zambia to gain proper knowledge on the general accessibility of poor consumers to fish species, which aren't commonly sold in the Lusaka area. Furthermore actions have to be taken to at least stabilize natural fish stocks, for example by enforcing sustainable fishing practices. Additionally, small fish species such as Kapenta or species whose juvenile forms can be consumed whole such as Matuku should be introduced into the growing aquaculture sector, maybe by promoting and supporting small and medium aquaculture enterprises, which could further function as an additional source of income (Genschick et al. 2017). This diversification of aquaculture (with species, which are rich in micronutrients and more accessible for the poor) could be an important step in combating hidden hunger in Zambia.

Acknowledgements The authors would like to thank the Department of Fisheries Zambia, Carl Huchzermeyer, Moses Banda, Pamela Marinda and Nyambe Lisulo Mkandawire for their great support during the sample collection process. The authors would also like to thank SGS Institut Fresenius for their part in the laboratory analysis and Aaron Willmott for his editing of the manuscript. This study was conducted with the financial support of the Federal Ministry for Economic Cooperation and Development (BMZ), Germany.

Funding Open Access funding enabled and organized by Projekt DEAL.

\section{Compliance with ethical standards}

Conflict of interest The authors declare no conflict of interest.

Open Access This article is licensed under a Creative Commons Attribution 4.0 International License, which permits use, sharing, adaptation, distribution and reproduction in any medium or format, as long as you give appropriate credit to the original author(s) and the source, provide a link to the Creative Commons licence, and indicate if changes were made. The images or other third party material in this article are included in the article's Creative Commons licence, unless indicated otherwise in a credit line to the material. If material is not included in the article's Creative Commons licence and your intended use is not permitted by statutory regulation or exceeds the permitted use, you will need to obtain permission directly from the copyright holder. To view a copy of this licence, visit http://creativecommons.org/licenses/by/4.0/. 


\section{References}

Béné, C., \& Heck, S. (2005). Fish and food security in Africa. NAGA, WorldFish Center Quarterly, 28(3-4), 8-13.

Biesalski, H. K. (2013). Der verborgene Hunger: Satt sein ist nicht genug: Springer-Verlag.

Bogard, J. R., Thilsted, S. H., Marks, G. C., Wahab, M. A., Hossain, M. A. R., Jakobsen, J., \& Stangoulis, J. (2015). Nutrient composition of important fish species in Bangladesh and potential contribution to recommended nutrient intakes. Journal of Food Composition and Analysis, 42, 120-133. https://doi.org/10.1016/j.jfca.2015.03.002.

Brækkan, O. R. (1956). Function of the red muscle in fish. Nature, 178(4536), 747-748.

Central Statistical Office (CSO). (2016). 2015 Living Conditions Monitoring Survey Key Findings. https:/www.zamstats.gov.zm/phocadownload/ Living Conditions/2015\%20Living\%20Conditions\%20Monitoring\% 20Survey\%20Report.pdf. Accessed 16 July 2018.

Central Statistical Office (CSO), Ministry of Health, and ICF International. (2014) "Zambia Demographic and health survey 2013-14." https://www.dhsprogram.com/pubs/pdf/fr304/fr304.pdf

Erhardt, J. (2014). Nutrisurvey software version 2007. [updated 2012/04/ 04; cited 2007/08/08].

Ezilon Maps (2009). Zambia Map-Political Map of Zambia https://www. ezilon.com/maps/africa/zambia-maps.html.

FDA (2016). Federal Register/Vol. 81, No. 103 / Friday, May 27, 2016, Washington DC, USA.

Genschick, S., Kaminski, A. M., Kefi, A. S., \& Cole, S. M. (2017). Aquaculture in Zambia: An overview and evaluation of the sector's responsiveness to the needs of the poor. Zambia: World Fish and Department of Fisheries.

Genschick, S., Marinda, P., Tembo, G., Kaminski, A. M., \& Thilsted, S. H. (2018). Fish consumption in urban Lusaka: The need for aquaculture to improve targeting of the poor. Aquaculture, 492, 280-289. https://doi.org/10.1016/j.aquaculture.2018.03.052.

Halimatou, A., Kohler, L., Taren, D., Mofu, M., Chileshe, J., \& Kalungwana, N. (2014). Zambia food consumption and micronutrient status survey report. Lusaka: National Food and Nutrition Commission DRAFT.

Haug, A., Christophersen, O. A., Kinabo, J., Kaunda, W., \& Lo Eik. (2010). Use of dried Kapenta (Limnothrissa miodon and Stolothrissa tanganicae) and other products based on whole fish for complementing maize-based diets. African Journal of Food, Agriculture, Nutrition and Development, 10(5).

Hichaambwa, M. (2012). Urban consumption patterns of livestock products in Zambia and implications for policy: Citeseer.

Horton, S., Alderman, H., \& Rivera, J. A. (2008). The challenge of hunger and malnutrition. Copenhagen Consensus, 3-4.

Julshamn, K., Haugsnes, J., \& Eriksen, J. (1978). Major and minor element (mineral) levels in products and offal from the fishing industries. 0332-5083.

Kabahenda, M. K., Amega, R., Okalany, E., Husken, S. M. C., \& Heck, S. (2011). Protein and micronutrient composition of low-value fish products commonly marketed in the Lake Victoria region. World Journal of Agricultural Sciences, 7(5), 521-526.

Kaminski, A. M., Genschick, S., Kefi, A. S., \& Kruijssen, F. (2018). Commercialization and upgrading in the aquaculture value chain in Zambia. Aquaculture, 493, 355-364. https://doi.org/10.1016/j. aquaculture.2017.12.010.

Kawarazuka, N., \& Béné, C. (2011). The potential role of small fish species in improving micronutrient deficiencies in developing countries: Building evidence. Public Health Nutrition, 14, 1927-1938. doi:https://doi.org/10.1017/S1368980011000814.
Larsen, T., Thilsted, S. H., Kongsbak, K., \& Hansen, M. (2000). Whole small fish as a rich calcium source. British Journal of Nutrition, 83(2), 191-196.

Linhartová, Z., Krejsa, J., Zajíc, T., Másílko, J., Sampels, S., \& Mráz, J. (2018). Proximate and fatty acid composition of 13 important freshwater fish species in Central Europe. Aquaculture International, 26, 695-711. https://doi.org/10.1007/s10499-018-0243-5.

Longley, C., Haraksingh Thilsted, S., Beveridge, M., Cole, S., Banda Nyirenda, D., Heck, S., et al. (2014). The role of fish in the first 1, 000 days in Zambia.

Lukmanji, Z., Hertzmark, E., Mlingi, N., Assey, V., Ndossi, G., \& Fawzi, W. (2008). Tanzania food composition tables. MUHAS-TFNC, HSPH, Dar es Salaam Tanzania.

Marinda, P. A., Genschick, S., Khayeka-Wandabwa, C., KiwanukaLubinda, R., \& Thilsted, S. H. (2018). Dietary diversity determinants and contribution of fish to maternal and under-five nutritional status in Zambia. PLoS One, 13(9), e0204009.

Musumali, Musole M.; Heck, Simon; Husken, S. M.C.; Wishart, Marcus (2009): Fisheries in Zambia: An undervalued contributor to poverty reduction. In: WorldFish Center Policy Brief (1913).

National Food and Nutrition Commission of Zambia (NFNC) (2011). National Food and nutrition strategic plan 2011-2015. NFNC; 2011.

Nayak, S. K. (2010). Role of gastrointestinal microbiota in fish. Aquaculture Research, 41(11), 1553-1573.

Nyirenda, D. B. (2009). Zambia food composition tables (4th ed.). Lusaka: National Food and Nutrition Commission.

Nyirenda, D. B., Musukwa, M., \& Mugode, R. H. (2007). The common Zambian foodstuff, ethnicity, preparation and nutrient composition of selected foods. Ministry of Health: Lusaka and Boston University MA.

Owino, V., Amadi, B., Sinkala, M., Filteau, S., \& Tomkins, A. (2008). Complementary feeding practices and nutrient intake from habitual complementary foods of infants and children aged 6-18 months old in Lusaka, Zambia. African Journal of Food, Agriculture, Nutrition and Development, 8(1), 28-47.

Roos, N., Leth, T., Jakobsen, J., \& Thilsted, S. H. (2002). High vitamin A content in some small indigenous fish species in Bangladesh: Perspectives for food-based strategies to reduce vitamin A deficiency. International Journal of Food Sciences and Nutrition, 53, 425437. https://doi.org/10.1080/0963748021000044778.

Roos, N., Wahab, M. A., Chamnan, C., \& Thilsted, S. H. (2007). The role of fish in food-based strategies to combat vitamin a and mineral deficiencies in developing countries. The Journal of Nutrition, 137, 1106-1109. https://doi.org/10.1093/jn/137.4.1106.

Stadlmayr, B., Charrondiere, U. R., Enujiugha, V., Bayili, R. G., Fagbohoun, E. G., Samb, B., et al. (2012). West African food composition table., 92500720.

Steiner-Asiedu, M., Lied, E., Lie, Ø., Nilsen, R., \& Julshamn, K. (1993). The nutritive value of sun-dried pelagic fish from the rift valley in Africa. Journal of the Science of Food and Agriculture, 63, 439443. https://doi.org/10.1002/jsfa.2740630410.

Swanson, D., Block, R., \& Mousa, S. A. (2012). Omega-3 fatty acids EPA and DHA: Health benefits throughout life. Advances in nutrition (Bethesda, Md.), 3, 1-7 (2012). https://doi.org/10.3945/an.111.000893.

Thilsted, S. H., Thorne-Lyman, A., Webb, P., Bogard, J. R., Subasinghe, R., Phillips, M. J., \& Allison, E. H. (2016). Sustaining healthy diets: The role of capture fisheries and aquaculture for improving nutrition in the post-2015 era. Food Policy, 61, 126-131. https://doi.org/10. 1016/j.foodpol.2016.02.005.

Tweddle, D., Cowx, I. G., Peel, R. A., \& Weyl, O. L. F. (2015). Challenges in fisheries management in the Zambezi, one of the great rivers of Africa. Fisheries Management and Ecology, 22, 99-111. https://doi.org/10.1111/fme.12107.

Whitehead, P.J.P. (1985). FAO Species Catalogue. Vol. 7. Clupeoid fishes of the world (suborder Clupeoidei). An annotated and illustrated catalogue of the herrings, sardines, pilchards, sprats, shads, anchovies and wolf-herrings. FAO Fish. Synop. 125(7/1):1-303. Rome: FAO. 


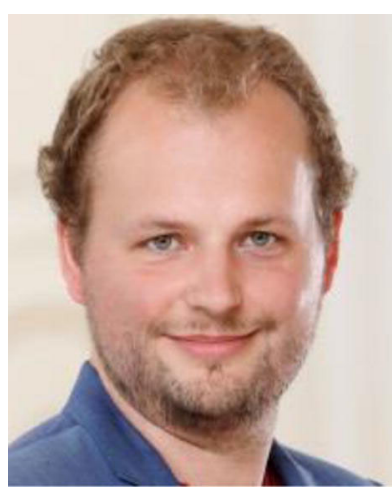

Nils Nölle is a doctoral student at the institute of Nutritional sciences at the University of Hohenheim in Stuttgart, Germany. He holds a Master of Science in Molecular Nutrition and a Bachelor of Science in Nutrition, both obtained at the University Hohenheim. His overall research topic focuses on the potential of either underutilized traditional foods or novel value added products to combat malnutrition in developing countries, mainly on the African continent. His projects included studies on the (micro)nutrient composition of indigenous fish species in Zambia, the biofortification of mushrooms with vitamin D through UV-treatment e.g. sun-drying for potential uses in Ethiopia, and the micronutrient composition of edible insects in in Kenya and Uganda.

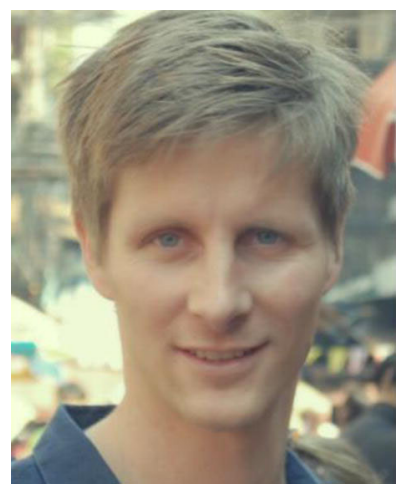

Sven Genschick is an Advisor for Sustainable Fisheries and Aquaculture at GIZ (Deutsche Gesellschaft für Internationale Zusammenarbeit) in Eschborn, Germany. Dr. Genschick has several years of professional research experience on small-scale aquaculture and fish value chains with a regional focus on Southeast Asia \& Sub-Saharan Africa. In his $\mathrm{PhD}$ dissertation, he applied a social science perspective on Pangasius aquaculture in the Mekong Delta, Vietnam, to analyze the interplay of subjective and objective structures that impose on the conduct of sustainable practices in fish cultivation. As post-doctoral fellow with WorldFish (CGIAR) his research focus shifted towards nutritionsensitive production systems in small-scale aquaculture and related fish value chains. He has spent the past four years researching potentials for sustainable intensification and improvement of food and nutrition security through aquaculture and related value chain interventions in developing countries, mostly in Bangladesh, Kenya, Malawi and Zambia. He is passionate about making smallholders harness economic and nutritional benefits for the whole family from sustainable aquaculture.

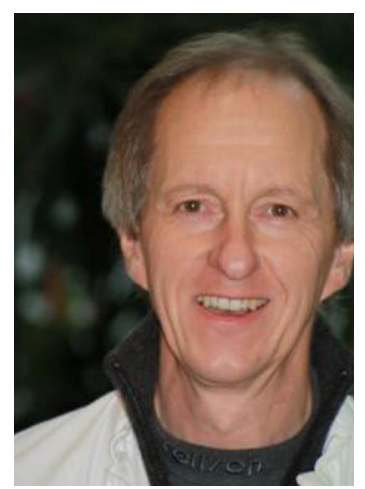

Klaus Schwadorf is a scientific staff member of the Core Facility Hohenheim (University of Hohenheim, Stuttgart, Germany). He studied food \& analytical chemistry at the University of Stuttgart (Germany) and has a $\mathrm{PhD}$ in agricultural chemistry from University of Hohenheim. His main fields of work and research interests are in chromatographic and spectrometric analysis. The range of substances includes feed and food ingredients, additives, undesirable substances or (environmental) contaminants such as mycotoxins, pesticides, organochlorine components, etc..

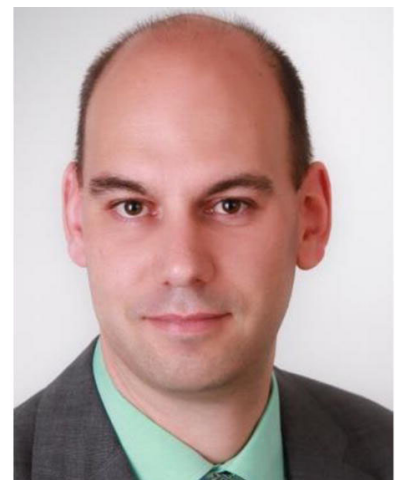

Holger Hrenn is a scientific staff member of the Core Facility Hohenheim (University of Hohenheim, Stuttgart, Germany). $\mathrm{He}$ has a $\mathrm{PhD}$ in food chemistry from University of Hohenheim. His research interest is about nutrient composition of plant material (e.g. animal feed) and the development of analytical methods. In addition, he works with coupling of gas chromatography and mass spectrometry for the analysis of metabolites and contaminants.

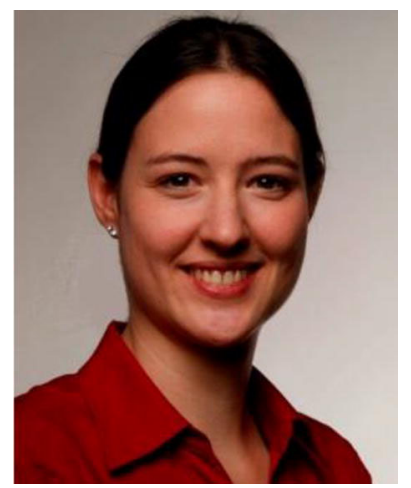

Sonja Brandner is a food chemist, who graduated from the University of Hohenheim. In her diploma thesis, she dealt with the fatty acid distribution of moldcontaminated food and the mold fungi obtained fromit. She completed the second state examination at the Chemisches und Veterinäruntersuchungsamt Stuttgart. She then worked as Laboratory Manager for Inorganic Analysis in the Analytical Chemistry Unit of the Core Facility Hohenheim in Stuttgart. There she analyzed the contents of minerals, trace elements and heavy metals in agricultural samples of various matrices, e.g. food and feed, as well as plant, animal and soil samples. The analyzes were performed using various methods of analysis including ICP-OES, ICPMS and HGAAS. 


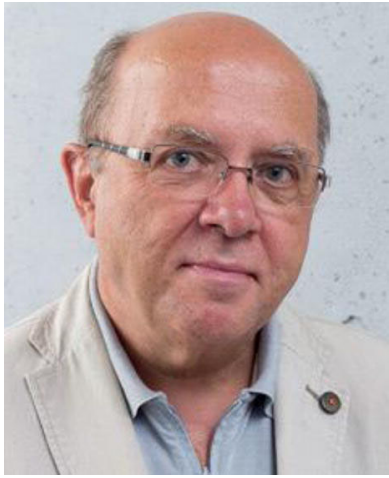

Prof. Dr. med. Hans Konrad Biesalski was head of the Institute of Biological Chemistry and Nutrition as well as Director of the Food Security Center (FSC) at the University of Hohenheim in Stuttgart, Germany First, his research activities have concentrated on antioxidants and vitamins in basic and applied research on reactive oxygen species and their role in human nutrition. Since 2010, his research is related to food quality as an indicator of adequate and healthy nutrition and micronutrients in human health and disease. Prof. Dr. Biesalski is Editor of the journal "Nutrition and metabolism in cancer" as well as European Editor of "Nutrition and Metabolism". He has edited 7 textbooks related to nutrition medicine, nutrition physiology, clinical nutrition and aging (some of them translated in English, French, Spanish and Chinese) and published more than 330 peer-reviewed papers in the most prestigious scientific journals dealing with nutrition, vitamins and nutrition medicine. He organized and chaired several international conferences. As Principle Investigator of nutrition studies in developing countries, he studied the impact of DDT on vitamin A status in refugee camps, nutrition and food quality including RUF (ready-to-use food) in developing countries, the impact of climate change on food quality and the characterization of Ethiopian edible oils and its improved use in Ethiopian diets. Furthermore, he has developed IT based programs (with specific scoring systems to detect malnutrition and micronutrient intake in different groups (children, pregnant women and elderly, cancer patients). Prof. Dr. Biesalski is a member of different international societies and vitamin consultative groups, e.g. the WHO/FAO Expert Group Application of Nanotechnologies in the Food and Agriculture Sectors (Potential Food Safety Implications), the FAO/WHO BOND Initiative (Biomarker of Nutritional Deficiencies) and the High Level Panel of Expert Group of the Global Forum on Food Security and Nutrition. In 2007, he was elected as scholar of the Institute of Advanced Studies, Berlin and in 2017 he got the prestigious Justus von Liebig Award. 